\title{
EFEITOS DE TRÊS LÂMINAS DE IRRIGAÇÃO E DE QUATRO DOSES DE POTÁSSIO VIA FERTIRRIGAÇÃO NO MELOEIRO EM AMBIENTE PROTEGIDO
}

\author{
ADRIANO JOSÉ SOARES
}

Dissertação apresentada à Escola Superior de Agricultura "Luiz de Queiroz", Universidade de São Paulo, para a obtenção do título de Mestre em Agronomia, Área de Concentração: Irrigação e Drenagem.

PIRACICABA

Estado de São Paulo

Dezembro- 2001 


\title{
EFEITOS DE TRÊS LÂMINAS DE IRRIGAÇÃO E DE QUATRO DOSES DE POTÁSSIO VIA FERTIRRIGAÇÃO NO MELOEIRO EM AMBIENTE PROTEGIDO
}

\author{
AdRIANO José SOARES
}

Engenheiro Agrônomo

Orientador: Prof. Dr. MARCOS VINÍCIUS FOLEGATTI

Dissertação apresentada à Escola Superior de Agricultura "Luiz de Queiroz", Universidade de São Paulo, para a obtenção do título de Mestre em Agronomia, Área de Concentração: Irrigação e Drenagem.

PIRACICABA

Estado de São Paulo

Dezembro- 2001 


\section{Dados Internacionais de Catalogação na Publicação (CIP) DIVISÃO DE BIBLIOTECA E DOCUMENTAÇÃO - ESALQ/USP}

Soares, Adriano José

Efeitos de três lâminas de irrigação e de quatro doses de potássio via

fertirrigação no meloeiro em ambiente protegido / Adriano José Soares. - -

Piracicaba, 2001.

67 p. : il.

Dissertação (mestrado) - - Escola Superior de Agricultura Luiz de Queiroz, 2001.

Bibliografia.

1. Estufas 2. Fertilizantes potássico 3. Fertirrigação 4. Irrigação por gotejamento 5. Melão I. Título

CDD 635.61

"Permitida a cópia total ou parcial deste documento, desde que citada a fonte - O autor" 


\section{Eu não me envergonho de comigir e de mudar minhas opiniões, porque não me envergonho de raciocinar $e$ de aprender.}


Aos meus pais Francisco José Soares e Celia R. Pinato Gonçalves Soares pelo apoio, pelo amor e pelo incentivo durante toda esta etapa de minha vida, Dedico esta conquista com o mais profundo amor, com admiração e respeito.

Aos meus irmãos, às minhas queridas sobrinhas, Isabela e Beatriz Maria, e especialmente à minha avó, Isaltina Pinato, 0 fereço. 


\section{AGRADECIMENTOS}

À Deus, que sempre me iluminou e me deu forças para caminhar e ultrapassar os obstáculos surgidos em meu caminho;

Ao Departamento de Engenharia Rural da Escola Superior de Agricultura "Luiz de Queiroz", pela oportunidade oferecida para o desenvolvimento deste trabalho;

À Coordenação de Aperfeiçoamento de Pessoal de Nível Superior, pela concessão da bolsa e dos recursos financeiros utilizados no projeto de pesquisa;

Ao Prof. Dr. Marcos Vinícius Folegatti, pela confiança e pelo apoio dado para a realização deste curso, bem como pela orientação e pelo incentivo no desenvolvimento deste trabalho;

Aos Professores Dr. José Antônio Frizzone, Dr.Rubens Duarte Coelho, Dr. Sergio Nascimento Duarte, Dr. Tarlei Arriel Botrel, e Dr. Décio Eugênio Cruciani, pelos ensinamentos oferecidos durante a realização do curso e pelas sugestões para o melhoria e o engrandecimento deste trabalho;

Ao Dr. Valdemício Ferreira de Sousa da Empresa Brasileira de Pesquisa Agropecuaria, pela contribuição na elaboração do projeto de pesquisa e no desenvolvimento do tema;

Ao Prof Luis Arthur Alvarenga Vilela, pelos ensinamentos passados e pela credibilidade depositada;

Aos colegas do Curso de Pós-Graduação em Irrigação e Drenagem: Flavio Favaro Blanco, Rodrigo Otávio Rodrigues, Luis Fernando Campeche, Roberto Terumi Atarassi, Enio Farias de França e Silva, Raquel Trevizam, Leonardo Batista da Silva, 
Carmelo Crisafulli Machado, Anderson Soares, Ariovaldo Tadeu Lucas, Jocelito Sacol de Sá, Alexandre Xavier, Valter Dantas, Luís Fernando Farias, Wellington Farias de Araújo, Maurício A. Coelho, Fátima Rezende Filho, pelas valiosas idéias e pela colaboração na execução das análises de dados do experimento bem como pela amizade, pelos companheirismo e pelos muitos momentos de alegria;

Aos demais colegas do Curso de Pós-Graduação em Irrigação e Drenagem, pela saudável convivência e pelo apoio durante o curso;

Aos funcionários do Departamento de Engenharia Rural da ESALQ/USP, pela convivência e pela colaboração e pelos serviços prestados durante a instalação e a execução do experimento em campo;

Aos estudantes do curso de Graduação em Engenharia Agronômica da ESALQ/USP e aos membros do Grupo de Práticas em Irrigação e Drenagem "GPID" Lingote, Dreer, D-menor, pela colaboração durante a instalação, a condução, e a coleta dos dados do experimento;

A todos aqueles que, de uma forma ou de outra, contribuíram para a realização deste trabalho. 


\section{SUMÁRIO}

Página

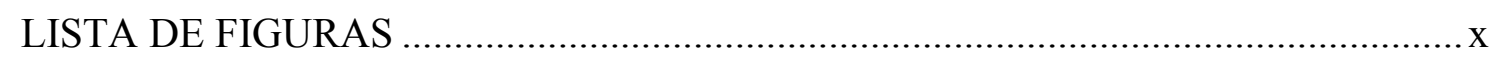

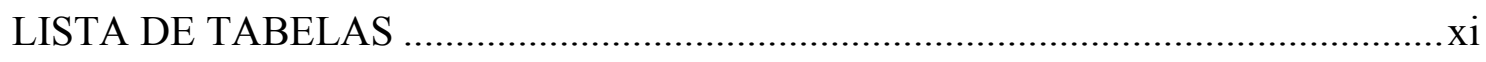

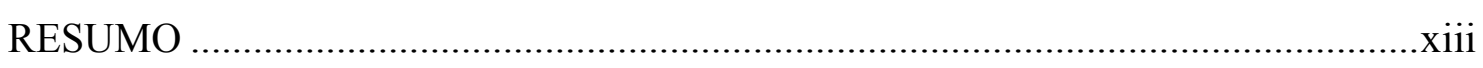

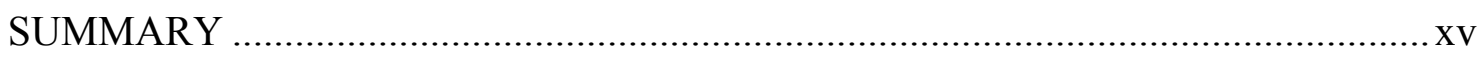

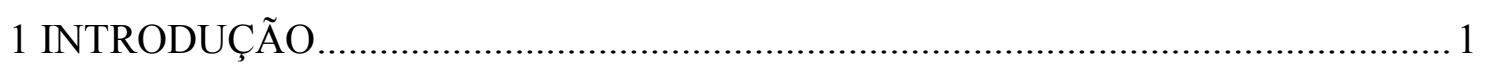

2 REVISÃO DE LITERATURA .................................................................. 4

$2.1 \quad$ A Cultura do Meloeiro................................................................................... 4

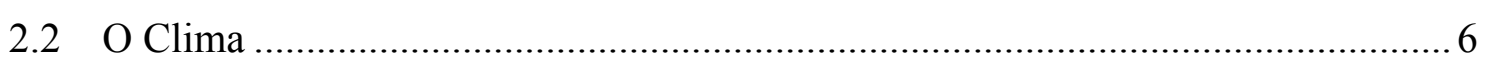

$2.2 .1 \quad$ Elementos Meteorológicos ............................................................... 7

$2.2 .1 .1 \quad$ Temperatura e Umidade Relativa .................................................................. 8

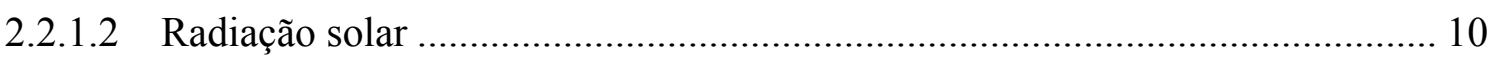

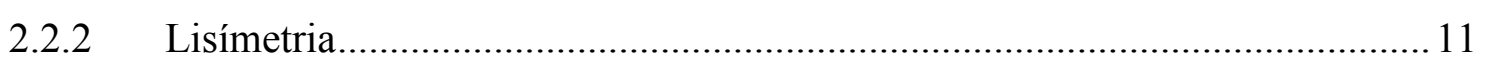

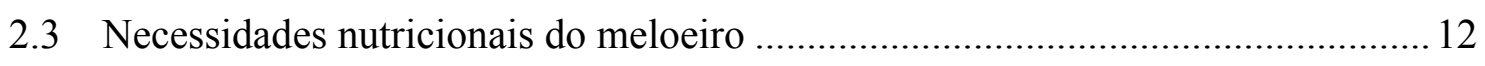

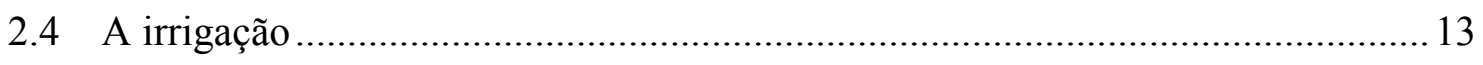

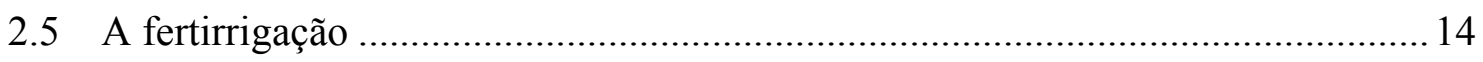

3 MATERIAL E MÉTODOS ............................................................................. 17

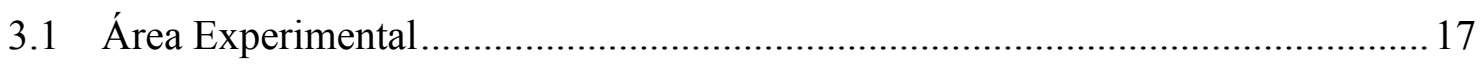

3.2 Descrição das estruturas experimentais................................................... 17

3.3 Preparo do Solo, Adubação, Transplantio das mudas .................................... 20

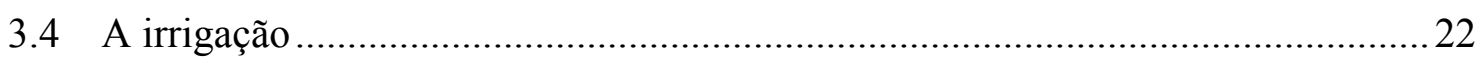

3.4.1 Monitoramento dos elementos climáticos e da evapotranspiração no ambiente

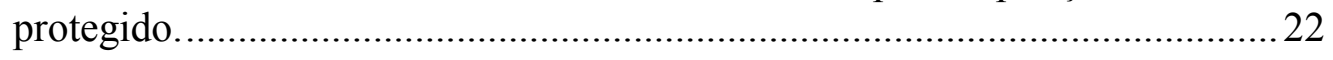

3.4.1.1 Radiação solar global ........................................................................... 22

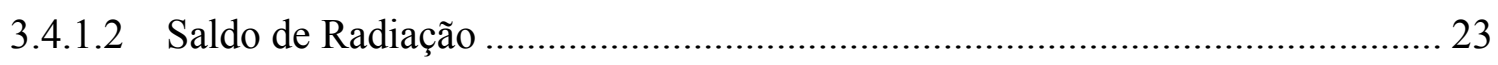


3.4.1.3 Temperatura e Umidade Relativa do ar.................................................... 23

3.4.1.4 Fluxo de calor no solo ..................................................................... 23

3.4.1.5 O lisímetro ......................................................................................... 24

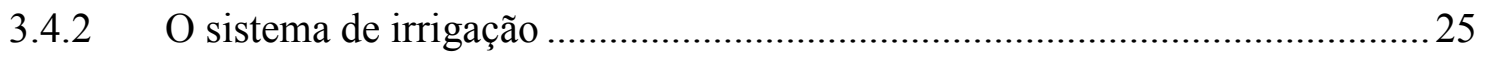

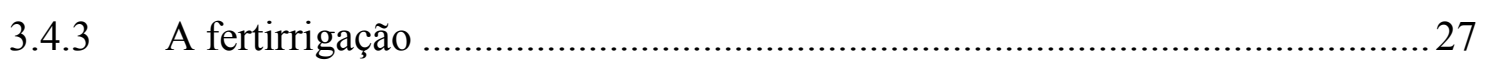

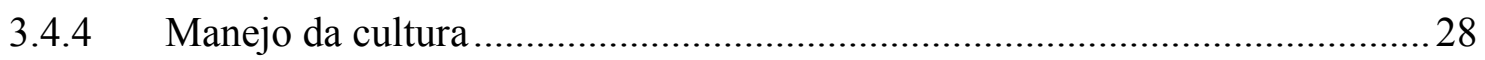

$3.4 .5 \quad$ Produtividade e Classificação dos frutos..................................................... 30

3.4.6 Parâmetros de qualidade dos frutos ........................................................... 31

4 RESULTADOS E DISCUSSÃO …............................................................. 32

$4.1 \quad$ Manejo da água........................................................................................... 32

$4.1 .1 .1 \quad$ Condutividade elétrica...................................................................... 37

$4.1 .1 .2 \quad$ Produtividade...................................................................................... 38

4.1.1.3 Produtividade Comercial .................................................................... 40

$4.1 .1 .4 \quad$ Produtividade não comercial ...................................................................... 44

4.1 .1 .5 Produtividade total ......................................................................... 46

4.2 Parâmetros de qualidade nos frutos...............................................................49

$4.2 .1 \quad$ Parâmetros Físicos................................................................................... 49

4.2.1.1 Diâmetro e comprimento ......................................................................... 49

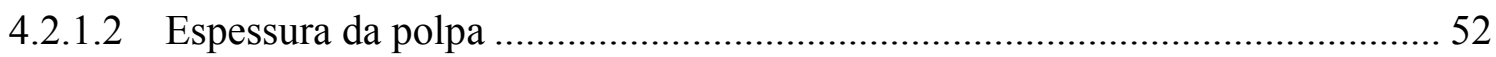

$4.2 .2 \quad$ Parâmetros Químicos............................................................................53

$4.2 .2 .1 \quad$ Sólidos Solúveis Totais ........................................................................... 53

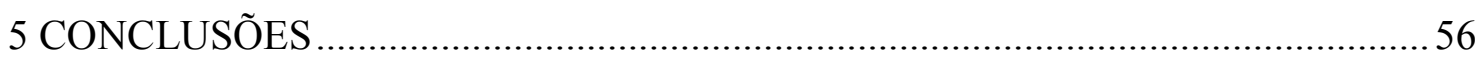

REFERÊNCIAS BIBLIOGRÁFICAS ............................................................ 57 


\section{LISTA DE FIGURAS}

Página

1 Índices estacionais de comercialização na CEAGESP no período de 1991 a 1995 (Adaptado de Dias et al., 1997) ................................................................ 7

2 Ambiente protegido do Departamento de Engenharia Rural da ESALQ/USP...... 18

3 Croqui de campo dos ambientes protegidos e tratamentos. ................................. 19

4 Vista lateral do lisímetro e planta baixa do apoio de sustentação da célula de carga em formato "V" ..............................................................................25

5 Evapotranspiração do meloeiro, determinada no período de abril/2001 a julho/2001, em um lisímetro de pesagem............................................. 33

6 Variação média da temperatura do ar interna e externa, no período experimental. . 34

7 Variação do potencial matricial da água no solo para o tratamento $L_{1}$ a $0,30 \mathrm{~m}$ de profundidade nos dias após transplantio................................................. 36

8 Variação do potencial matricial da água no solo para o tratamento $L_{2}$ a $0,30 \mathrm{~m}$ de profundidade nos dias após transplantio................................................. 36

9 Variação do potencial matricial da água no solo para o tratamento $\mathrm{L}_{3}$ a $0,30 \mathrm{~m}$ de profundidade nos dias após transplantio.................................................. 36

10 Condutividade elétrica do extrato de saturação $\mathrm{CE}_{\mathrm{es}}$, para as profundidades de

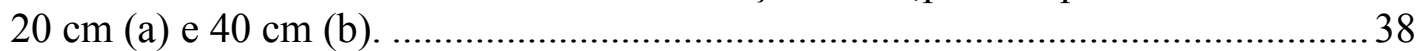

11 Produtividade não comercial (PNC), total (PT) e comercial (PC) do meloeiro, submetido a diferentes doses de potássio e a diferentes lâminas de água................39

12 Efeito da interação entre as doses de potássio aplicadas por fertirrigação e os níveis de irrigação $\mathrm{L}_{2}(\mathrm{a})$ e $\mathrm{L}_{3}(\mathrm{~b})$, respectivamente, na produtividade do meloeiro .. 42

13 Frutos de melão híbrido 'Don Carlos' e seus respectivos tratamentos ..................43

14 Efeito da interação entre as doses de potássio aplicadas por fertirrigação e os níveis de irrigação L1(a), L2(b) e L3(c) na produtividade não comercial. ..............46

15 Efeitos da interação entre as doses de potássio aplicadas por fertirrigação e os níveis de irrigação $\mathrm{L}_{2}(\mathrm{a}) \mathrm{L}_{3}(\mathrm{~b})$, na produtividade total do meloeiro...................... 48 


\section{LISTA DE TABELAS}

Página

Coeficientes da equação de van Genuchten. .....................................................20

2 Resultados da análise de fertilidade do solo no início do período experimental. ( Macronutrientes e Micronutrientes).

3 Granulometria e classe textural do solo em diferentes profundidades, no início do período experimental................................................................................21

4 Produtos químicos utilizados no decorrer do experimento …...............................30

5 Amplitude de peso em caixa de 10kg para meloeiro............................................... 31

6 Valores mensais e totais de volume de água aplicados por meio de irrigação por gotejamento nos respectivos tratamentos.............................................................. 32

7 Análise de variância para a produtividade comercial.......................................... 40

8 Valores médios de produtividade comercial de frutos de meloeiro $\left(\mathrm{t} \mathrm{ha}{ }^{-1}\right)$, sob diferentes níveis de irrigação e diferentes doses de potássio aplicadas por fertirrigação. ................................................................................................... 41

9 Análise de variância para a produtividade não comercial ....................................... 44

10 Produtividade não comercial do meloeiro $\left(\mathrm{t} \mathrm{ha}^{-1}\right)$ sob diferentes níveis de irrigação e diferentes doses de potássio aplicadas por fertirrigação.........................4

11 Análise de variância para a produtividade total .....................................................4

12 Produtividade total do meloeiro $\left(\mathrm{t} \mathrm{ha}^{-1}\right)$ sob diferentes níveis de irrigação $\mathrm{e}$ diferentes doses de potássio aplicadas por fertirrigação.......................................... 47

13 Análise de variância para o diâmetro médio dos frutos .......................................... 49

14 Diâmetro de frutos de meloeiro $(\mathrm{mm})$ sob diferentes níveis de irrigação e diferentes doses de potássio aplicadas por fertirrigação..........................................50

15 Análise de variância para o comprimento médio dos frutos. ..................................51

16 Comprimento de frutos de meloeiro $(\mathrm{mm})$ sob diferentes níveis de irrigação e diferentes doses de potássio aplicadas por fertirrigação..........................................51

17 Análise de variância para a espessura da polpa do meloeiro....................................52 
18 Espessura de polpa de frutos de meloeiro $(\mathrm{mm})$ sob diferentes níveis de irrigação e diferentes doses de potássio aplicadas por fertirrigação.......................53

19 Análise de variância para o teor de sólidos solúveis totais. .................................54

20 Valores médios de sólidos solúveis totais ( ${ }^{\circ}$ Brix) de frutos de meloeiro sob diferentes níveis de irrigação e diferentes doses de potássio aplicadas por

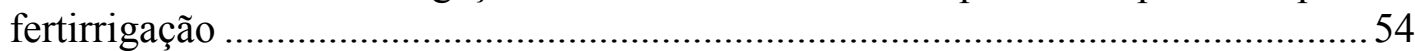




\section{EFEITOS DE TRÊS LÂMINAS DE IRRIGAÇÃO E DE QUATRO DOSES DE POTÁSSIO VIA FERTIRRIGAÇÃO NO MELOEIRO EM AMBIENTE PROTEGIDO}

Autor: ADRIANO JOSÉ SOARES

Orientador: Prof. Dr. MARCOS VINICIUS FOLEGATTI

\section{RESUMO}

Este trabalho teve como objetivo estudar os efeitos de três lâminas de irrigação e de quatro doses de potássio aplicadas via água de irrigação por gotejamento na produtividade e na qualidade dos frutos de melão (Cucumis melo L.), cv. Dom Carlos, com espaçamento de 1,2 m x 0,4 m. Visa também determinar os níveis de irrigação e as doses de potássio mais adequados para o meloeiro, cultivado sob fertirrigação em ambiente protegido no período de outono-inverno. $\mathrm{O}$ experimento foi realizado no período de abril/2000 à julho/2000 no Departamento de Engenharia Rural da ESALQ/USP. Foi utilizado delineamento experimental inteiramente casualizado com três repetições, em esquema fatorial 4 x 3. Os tratamentos resultam da combinação de três lâminas de irrigação $\left(\mathrm{L}_{1}=50 \%\right.$ Etc, $\mathrm{L}_{2}=75 \%$ ETc e $\mathrm{L}_{3}=100 \%$ da ETc) e de quatro doses de potássio $\left(\mathrm{K}_{1}=30 ; \mathrm{K}_{2}=90 ; \mathrm{K}_{3}=150\right.$ e $\mathrm{K}_{4}=210 \mathrm{~kg}$ de $\mathrm{K}_{2} \mathrm{O}$ há $\left.{ }^{-1}\right)$. A fertirrigação foi realizada a cada dois dias, utilizando-se tanques onde os fertilizantes eram dissolvidos na água de irrigação. O monitoramento da umidade do solo foi feito com tensiômetros instalados em torno da planta; pelos valores de potencial mátrico, a lâmina de irrigação 
$\mathrm{L}_{3}$ manteve o perfil de distribuição de água mais constante do que os de $\mathrm{L}_{1}$ e $\mathrm{L}_{2}$. As produtividades, comercial, não comercial e total, foram influenciadas pelos níveis de irrigação, pelas doses de potássio e pela interação entre eles, sendo as maiores produtividades totais de 29,7 e $27 \mathrm{tha}^{-1}$, obtidas com as combinações de $150 \mathrm{~kg}$ de $\mathrm{K}_{2} \mathrm{O}$ ha $^{-1}$ e $105 \mathrm{~L}_{\text {planta }}{ }^{-1}$ ciclo $^{-1}\left(\mathrm{~K}_{3} \mathrm{~L}_{2}\right)$ e $150 \mathrm{~kg}$ de $\mathrm{K}_{2} \mathrm{O} \mathrm{ha}^{-1}$ e $140 \mathrm{~L}$ por planta por ciclo $\left(\mathrm{K}_{3} \mathrm{~L}_{3}\right)$, respectivamente. Já as maiores produtividades comerciais foram $12,6 \mathrm{e} 10 \mathrm{t} \mathrm{ha}^{-1}$, obtidas com as combinações $30 \mathrm{~kg}$ de $\mathrm{K}_{2} \mathrm{O}$ ha $^{-1}$ e $105 \mathrm{~L}_{\text {planta }}{ }^{-1}$ ciclo $^{-1}\left(\mathrm{~K}_{1} \mathrm{~L}_{2}\right)$ e $210 \mathrm{~kg}$ de $\mathrm{K}_{2} \mathrm{O}$ ha $^{-1}$ e $140 \mathrm{~L}_{\text {planta }}{ }^{-1}$ ciclo $^{-1}\left(\mathrm{~K}_{4} \mathrm{~L}_{3}\right)$, respectivamente. 


\title{
EFFECT OF THREE IRRIGATION WATER DEPTHS AND FOUR POTASSIUM LEVELS APPLIED BY FERTIGATION ON MELON CROP UNDER PROTECTED ENVIRONMENT
}

\author{
Author: ADRIANO JOSÉ SOARES
}

Adviser: Prof. Dr. MARCOS VINICIUS FOLEGATTI

\section{SUMMARY}

The objective of this work was to study the effects of irrigation water depths and potassium levels applied by drip irrigation on yield and fruit quality of melon (Cucumis melo L.), cv. Dom Carlos, spaced 1,2 m x 0,4 m between rows and plants, respectively, and to determine the irrigation depths and potassium levels most suitable for fertigated melon cultivated in a greenhouse in the autumn-summer season. The trial was accomplished from april/2000 to june/2000 at the Departamento de Engenharia Rural of ESALQ/USP. The treatments were completely randomized with three replications in a factorial scheme $4 \times 3$, and resulted from a combination of three irrigation water depths $\left(\mathrm{L}_{1}=50 \%\right.$ ETc, $\mathrm{L}_{2}=75 \%$ ETc and $\left.\mathrm{L}_{3}=100 \% \mathrm{ETc}\right)$ and four potassium levels $\left(\mathrm{K}_{1}=1,45 ; \mathrm{K}_{2}=4,35 ; \mathrm{K}_{3}=7,25\right.$ and $\mathrm{K}_{4}=10,15 \mathrm{~g}$ of $\mathrm{K}_{2} \mathrm{O}$ plant $^{-1}$ season $\left.^{-1}\right)$. Fertigation was taken every two days using tanks where fertilizers were dissolved in the irrigation water. Soil moisture monitoring was made by tensiometers installed around the plant. From the matric potential values, the irrigation depth $\mathrm{L}_{3}$ maintained the water 
distribution pattern more constant than the $\mathrm{L}_{1}$ and $\mathrm{L}_{2}$. The marketable, non-marketable and total yields were modified by the irrigation depths, potassium levels and their interaction, with the higher total yields (29.7 and 27.0 ton $\mathrm{ha}^{-1}$ ) obtained with the combination of $150 \mathrm{~kg} \mathrm{~K}_{2} \mathrm{O}$ ha $^{-1}$ and $105 \mathrm{~L} \mathrm{plant}^{-1}$ season $^{-1}\left(\mathrm{~K}_{3} \mathrm{~L}_{2}\right)$ and $150 \mathrm{~kg} \mathrm{~K}_{2} \mathrm{O} \mathrm{ha}^{-1}$ and $140 \mathrm{~L} \mathrm{plant}^{-1}$ season $^{-1}\left(\mathrm{~K}_{3} \mathrm{~L}_{3}\right)$, respectively. The higher marketable yields were 12.6 and 10.0 ton ha ${ }^{-1}$, obtained with the combinations of $30 \mathrm{~kg} \mathrm{~K}_{2} \mathrm{O} \mathrm{ha}^{-1}$ and $105 \mathrm{~L}_{\text {plant }}{ }^{-1}$ season $^{-1}\left(\mathrm{~K}_{1} \mathrm{~L}_{2}\right)$ and $210 \mathrm{~kg} \mathrm{~K}_{2} \mathrm{O} \mathrm{ha}^{-1}$ and $140 \mathrm{~L}_{\text {plant }}{ }^{-1}$ season $^{-1}\left(\mathrm{~K}_{4} \mathrm{~L}_{3}\right)$, respectively. Fruits' physical and chemical parameters evaluated are in agreement with that demanded by market. 


\section{INTRODUÇÃO}

O meloeiro é uma olerícola pertencente à família Cucurbitaceae, ao gênero Cucumis e à espécie Cucumis melo, L. Após sua introdução no Brasil, por volta do ano de 1960, seu cultivo expandiu-se por várias localidades, como São Paulo, Pará e estados do Nordeste, e vem sendo realizado em larga escala no submédio São Francisco e nas microrregiões de Mossoró e Açú, no Rio Grande do Norte, (Sousa et al., 1999), devido às condições climáticas favoráveis.

O meloeiro é uma cultura rentável e de rápido retorno econômico. No Nordeste do Brasil, principal região produtora e exportadora de melão, a produtividade pode ultrapassar as 40 toneladas por hectare. Mas em regiões onde o clima não favorece o cultivo do meloeiro, é possível desenvolver técnicas para sua exploração em condições protegidas, que permitam a obtenção de altas produtividades, com frutos padronizados e de boa qualidade.

No Sudeste do Brasil, especialmente no estado de São Paulo, maior centro consumidor do país, o cultivo do melão, sob condições protegidas, vem sendo utilizado por pequenas propriedades, pois, além de elevar a produtividade da cultura, os produtores obtêm os melhores preços do mercado, dada a possibilidade de produzir na entressafra dos estados produtores da região Nordeste.

Sendo originário de regiões tropicais, o melão requer climas quentes e secos, ou seja, temperaturas elevadas e umidade não excessiva, pois, do contrário, seu desenvolvimento fica comprometido. (Filgueira 1981). 
O meloeiro é uma planta de crescimento rápido e seu desenvolvimento é afetado por vários fatores interligados, como a temperatura, a umidade relativa do ar, a aeração do solo e o número de horas de insolação. São eles que limitam - ou não - a produtividade do meloeiro.

O melão é uma das culturas mais exigentes com relação às características do solo, sendo as propriedades físicas, químicas e biológicas de grande importância na produção e na qualidade dos frutos. Não se recomenda o plantio em lugares de baixadas, assim como em solos muito pedregosos, de drenagem deficiente, onde a incidência de doenças no sistema radicular é favorecida.

Segundo Raij et al. (1991), o potássio é o elemento de maior mobilidade na planta e passa com facilidade de uma célula para outra, do xilema para o floema. Contudo sua disponibilidade é bastante influenciada pelo teor de água no solo, devido, principalmente, à difusão e à relação de cátions.

O manejo de água para a cultura do meloeiro é, sem dúvida, um dos aspectos que exige mais cuidados. A deficiência hídrica, que se manifesta na planta de diferentes formas e intensidades, pode se tornar a principal causa no decréscimo da produtividade. Por outro lado, existem limites de umidade para o bom desenvolvimento vegetativo. $\mathrm{O}$ teor de água ideal varia de acordo com uma série de fatores, mas, principalmente, com o estádio de desenvolvimento da cultura (Brandão et al. 1998).

O sistema de irrigação localizada, por gotejamento superficial, tem sido utilizado com sucesso em vários países, pois proporciona a aplicação de água e de nutrientes junto ao tronco da planta, onde há maior concentração de raízes. Permiti, assim, o controle da umidade e não se molha a parte aérea, o que reduz a incidência de doenças (Dusi 1992.).

Sabendo-se que esse sistema vem sendo aplicado nas culturas de alto retorno econômico, como de frutas e de hortaliças, é necessário desenvolver pesquisas para determinar o manejo da irrigação adequado à cultura, o que envolve, principalmente, as 
necessidades hídricas das culturas, a tensão de água no solo, as lâminas de água e a freqüência de irrigação adequada.

A forma tradicional de aplicação de fertilizantes nas culturas irrigadas vem sendo substituída pela fertirrigação e são poucas as culturas que têm uma recomendação específica para tal uso. Na prática, pela falta de informações, têm-se utilizado as recomendações dos boletins técnicos de adubação convencional. $\mathrm{O}$ uso do sistema de irrigação para aplicar fertilizantes permite o parcelamento dos mesmos em quantas vezes se fizerem necessárias, obedecendo-se as exigências da cultura, conforme as fases do seu ciclo (Sousa, 1993; Sousa et al., 1999). Assim, é necessário determinar as doses de nutrientes adequadas para a fertirrigação, bem como a lâmina de irrigação a ser aplicada para cada cultura, visando a um melhor aproveitamento dos recursos e minimizando os impactos ambientais.

Os objetivos deste trabalho foram: (i) estudar os efeitos de três lâminas de água e de quatro níveis de potássio, aplicados via fertirrigação por gotejamento, no desenvolvimento, na produtividade e na qualidade de frutos do meloeiro cultivado em ambiente protegido; (ii) determinar a melhor combinação entre a lâmina de irrigação e o nível de potássio para o meloeiro cultivado sob fertirrigação, em condições protegidas. 


\section{REVISÃO DE LITERATURA}

\subsection{A CUltura do MELOEIRO}

Pertencente à família Cucurbitaceae, ao gênero Cucumis e à espécie Cucumis melo, L., o meloeiro é uma olerícola cuja origem genética não está claramente estabelecida, sendo, para alguns autores, a África, enquanto, para outros, o oeste da Ásia. Segundo Lopes citado por Brandão (1998), os primeiros cultivos dessa espécie remontam aos egípcios, em 2400 a.C. Contudo, apenas a partir do século XVI, o melão foi levado a várias regiões de todo o mundo, originando a vasta gama de variedades, com diferentes formatos, cores, e tipos de frutos, que encontramos hoje.

No Brasil, a introdução do meloeiro ocorreu por volta dos anos 60 , sendo mais bem estabelecido em regiões quentes, apesar de se ter expandido para várias localidades do país.

Segundo Araújo (1980), o meloeiro é uma planta anual, herbácea, trepadeira ou rasteira, havendo, portanto, necessidade de condução específica, quando explorado comercialmente em ambiente protegido. Apresenta sistema radicular fasciculado, com crescimento abundante nos primeiros $0,30 \mathrm{~m}$ de profundidade de solo.

As flores são de sexo separado, axilares e isoladas; suas folhas são de tamanhos e formas bastante variadas, mas, em geral, grandes, palmadas, e pentalobadas, de disposição alternada. Das axilas das folhas, nascem as gavinhas, órgãos de sustentação

\footnotetext{
${ }^{1}$ LOPES, G. F.; Palestra de Abertura do Simpósio Brasileiro sobre Cucurbitaceas. Hortic. Brasileira, v 9, n2, p98-9, 1991
} 
da planta, e as flores, que podem ser monóicas, ginóicas ou, na sua maioria, andromonóicas (presença de flores masculinas e hermafroditas). A proporção é de cinco ou seis flores masculinas para uma flor feminina ou hermafrodita. A flor feminina é diclamídea de simetria radial pentâmera, com pétalas soldadas sem estaminódio, com estigma grande e trilobado, e ovário ínfero grande, tricarpelar e unilocular, com muitos óvulos. A flor masculina pentâmera diclamídea, de simetria radial, possui cinco estames livres, ou mais freqüente, unidos dois a dois pelas anteras e pela parte superior do filete, com longas tecas, no geral sigmóides e até retorcidas, (Joly, 1993).

Em sistemas de produção comercial, práticas como a polinização artificial do meloeiro devem ser feitas. A presença de tela anti-afideo, no ambiente protegido, faz com que ocorra a ausência da população dos agentes responsáveis pela polinização.

Devido às suas características de sabor apreciadas pelo mundo inteiro, o meloeiro tem expansão contínua há vários anos: seu crescimento no Brasil, nos últimos seis anos, foi de 50\% . Entretanto o cultivo do meloeiro no país sofreu grandes alterações, ora pelo ao desenvolvimento de novos híbridos, ora pela ampliação da sua distribuição geográfica e pelo aumento da área cultivada.

Com uma área plantada de 14 mil ha , o Brasil destaca-se como grande produtor mundial de melão. Dentre os estados produtores, destacam-se Rio Grande do Norte, Pará, Bahia, Ceará, Roraima, São Paulo, Minas Gerais, Rio Grande do Sul. Os estados do Nordeste aparecem com maior expansão da área plantada, entre 1999 e 2000, sendo uma atividade atrativa para pequenos produtores, uma vez que oferece um retorno econômico muito rápido (Brandão et al.,1998).

Nos últimos cinco anos, a produção brasileira cresceu muito, passando de 148.163 mil frutos, em 1997, para quase 200.000 mil frutos, em 2000, correspondendo a um incremento médio de $34 \%$; os estados do Nordeste foram os que mais cresceram, em cerca de $450 \%$, considerando-se o mesmo período.

Apesar de tal expansão, a produtividade apresentada pelos produtores é muito variada e, na maioria das vezes, baixa em relação ao potencial produtivo da cultura. Por 
isso, a literatura mostra que há necessidade de pesquisas para melhor definir as tecnologias de adubação, de irrigação e de manejo da cultura, capazes de propiciar um aumento da produtividade e da qualidade dos frutos, para que o produto possa competir melhor nos mercados, nacional e internacional.

A comercialização dos frutos de meloeiro é basicamente feita para consumo "in natura". As empresas exportadoras estão localizadas principalmente no Sudeste e no Nordeste do Brasil, e exportam anualmente cerca de 65.453 toneladas, (FPN Consult. \& Com., 1999).

Os maiores centros consumidores do Brasil encontram-se no Sudeste, destacando-se os estados de São Paulo e Rio de Janeiro, enquanto os maiores apreciadores internacionais do melão brasileiro são Holanda, Reino Unido, EUA, Alemanha, Itália, Argentina, Suécia, Dinamarca e Portugal.

\subsection{O CLIMA}

Durante o período entre agosto e janeiro, há um aumento na oferta de melão, com a conseqüente queda dos preços. Por outro lado, entre maio e julho, o melão recebe os melhores preços, em razão da baixa oferta. (Figura 1).

O conhecimento das exigências climáticas da cultura é um dos principais componentes da comercialização, permitindo uma definição das melhores épocas de plantio, de modo a coincidir a colheita com os períodos de melhores preços do produto. 


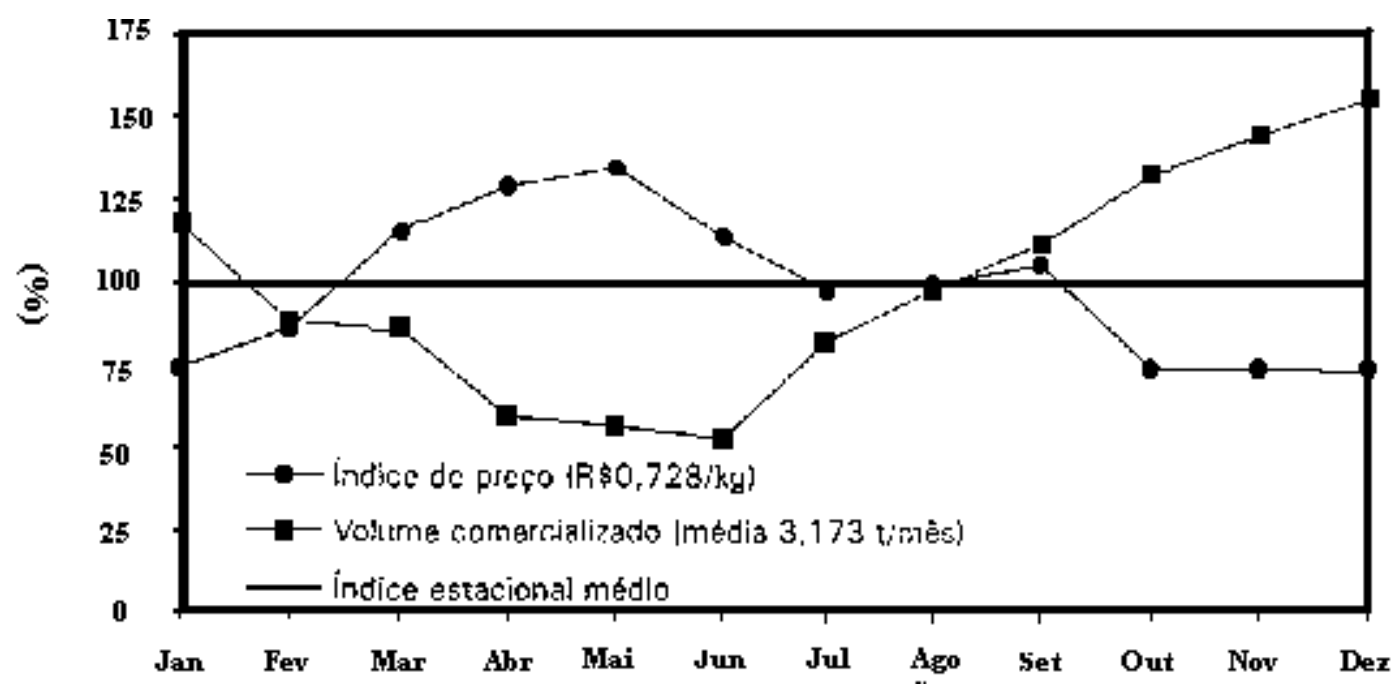

Figura 1 - Índices estacionais de comercialização na CEAGESP no período de 1991 a 1995 (Adaptado de Dias et al., 1997)

$\mathrm{Na}$ Figura 1, é apresentada a variação estacional do volume e dos preços de comercialização de melão, calculada com base na variação média histórica de 5 anos (1991-1995) de preços e de quantidades recebidas no CEAGESP.

\subsubsection{ELEMENTOS METEOROLÓGICOS}

Segundo Vila Nova (1987), é difícil separar a ação de cada um dos elementos meteorológicos na evapotranspiração, pois os mesmos agem simultaneamente. De maneira geral, em uma dada região, quanto maiores forem a disponibilidade de energia solar, a temperatura do ar, a velocidade do vento e quanto menor for a umidade relativa do ar, maior deverá ser a taxa de evaporação/evapotranspiração.

O cultivo protegido difere dos sistemas de produção a céu aberto, principalmente pelo uso intensivo do solo e pela possibilidade de controle dos fatores ambientais.

Embora sendo de origem tropical, o meloeiro pode ser cultivado em quase todas as regiões subtropicais. Altas temperaturas, alta luminosidade e baixa umidade relativa 
constituem a combinação de fatores climáticos mais adequada para o estabelecimento da cultura do meloeiro e para a obtenção de altas produtividades, com frutos de qualidade superior (Filgueira 1981).

\subsubsection{TEMPERATURA E UMIDADE RELATIVA}

A temperatura do ar é o elemento climático que exerce maior influência nos processos fisiológicos das plantas (Yang et al., 1994; Pezzopane et al., 1997; Vieira \& Cury, 1997). Assim, entre os fatores climáticos, ela é o mais importante também para o desenvolvimento do meloeiro. Sendo originário de regiões tropicais, o melão requer climas mais quentes e secos. Assim, temperaturas abaixo de $13^{\circ} \mathrm{C}$ reduzem o crescimento da planta, enquanto temperaturas entre $20^{\circ} \mathrm{C}$ e $30^{\circ} \mathrm{C}$ são favoráveis ao desenvolvimento e à produtividade (Silva et al., 2000).Segundo a Universidade da California, (1981), citada por Dusi (1992), os níveis de temperatura abaixo de $18^{\circ} \mathrm{C}$ dificultam a abertura das flores, ou mesmo induzem o abortamento de flores e frutos; por outro lado, temperaturas acima de $35^{\circ} \mathrm{C}$ podem também afetar o florescimento e a frutificação.

O crescimento da planta depende da quantidade de calor ao qual foi submetida, expresso em graus-dia de desenvolvimento (Chang 1968). Segundo este autor, graus-dia são a medida da diferença entre a temperatura média diária e uma temperatura base. Para Pazzopone et al.(1997), o conceito de graus-dia de desenvolvimento pressupõe a existência de uma temperatura base abaixo da qual a planta não se desenvolve e, se o fizer, será a taxas muito reduzidas. O autor afirma, ainda, que cada espécie vegetal ou cultivar possui uma temperatura base, que pode variar em função da fase fenológica da planta. O conceito de graus-dia de desenvolvimento assume que a relação entre a temperatura e o crescimento é linear, ao invés de logarítmica, como previsto pela lei de Van't Holf, (Chang, 1968). O valor de graus dia de desenvolvimento requerido para atingir determinado estádio fenológico é assumido como constante e independe do local 
ou da época de semeadura (Losada \& Angelocci, 1997). Uma crítica feita por esses autores a essa teoria é que ela não considera outros fatores que influênciam o crescimento e o desenvolvimento da planta; já com relação à temperatura base, criticam o fato de ser considerada constante, o que é uma aproximação, pois seu valor muda com o avanço da idade das plantas. Portanto a utilização de um valor inadequado de temperatura base ocasiona erro considerável na estimativa de graus-dia de desenvolvimento.

O meloeiro requer entre 2500 e 3000 graus de soma térmica, do plantio até a completa maturação, e cerca de 1000 graus de soma térmica são requeridos da floração até a colheita dos frutos, o que representa um ciclo de 75 a 80 dias, (Silva et al., 2000).

Os processos de transpiração e de fotossíntese respondem diretamente à temperatura da folha e são indiretamente afetados pelas reações estomáticas. A transpiração, em geral, aumenta com a temperatura, a menos que o estresse hídrico cause suficiente fechamento estomático que reverta essa tendência, a temperatura das folhas é dependente da radiação absorvida, da temperatura e da umidade relativa do ar (Gates \& Papain 1971).

O efeito da temperatura do ar sobre a temperatura das folhas é duplo. A temperatura do ar não apenas fornece a referência à qual a temperatura das folhas tendem , mas também sua elevação aumenta o déficit de pressão de vapor, aumentando a perda de calor latente, o que faz com que haja um diferencial entre a temperatura da folha e a do ar. Portanto a temperatura do ar ,interferindo na temperatura das folhas , indiretamente, interfere nos processos metabólicos e na transpiração da cultura (Jones, 1992) .

O teor de açúcares dos frutos está diretamente relacionado com as condições climáticas da produção. Temperaturas altas, aliadas à baixa umidade relativa do ar, suscitam a produção de frutos com teor de sólidos solúveis mais alto. Esses frutos são de melhor qualidade comercial e alcançam boas cotações no mercado (Dusi, 1992). 
A umidade relativa do ar pode afetar a evapotranspiração, e, como decorrência, causam mudanças na condutância estomática, afetando as interações com a fotossíntese e produção de matéria seca, e o índice de área foliar (Jolliet, 1994).

Embora a maioria das reações metabólicas seja fortemente influenciada pela temperatura, alguns processos físicos como a absorção de luz são relativamente insensíveis a ela,sendo a taxa de difusão de calor intermediária em sensibilidade (Jones, 1992).

\subsubsection{RADIAÇÃO SOLAR}

A cobertura plástica de estufas altera o balanço de radiação e o balanço energético, com relação ao exterior; em conseqüência, altera também a evapotranspiração.

Segundo Jones (1992), a radiação solar é a principal fonte de energia para as plantas, e a maior parte dessa energia é convertida em calor, impulsionando o processo de transpiração e também alterando a temperatura dos tecidos vegetais, com conseqüência para a taxa dos processos metabólicos e o balanço entre eles.

Embora a energia disponível possa ser utilizada nos diversos processos naturais, (fotossíntese, evapotranspiração, aquecimento do solo, das plantas e do ar), os processos de fotossíntese e aquecimento das plantas podem ser considerados quantitativamente insignificantes. Portanto, toda vez que a superfície estiver umedecida, a energia disponível será preferencialmente utilizada na evaporação. Como esse processo não é totalmente eficiente, há ainda uma sobra de energia, que é utilizada no aquecimento do solo e do ar . No entanto, quanto maior a deficiência hídrica, menor será a evaporação e maior a parte de energia disponível que será utilizada no aquecimento, resultando em grandes variações na temperatura (Pereira 1995). 


\subsubsection{LISIMETRIA}

Dentre os métodos diretos para a determinação da evapotranspiração, o lisímetro é o mais citado e o mais utilizado em nível experimental.

Lisímetros são dispositivos cheios de solo, localizados no campo com a finalidade de representar um ambiente específico. Podem apresentar a superfície nua ou coberta por uma vegetação, e prestam-se a determinar diretamente, a evapotranspiração no decorrer do desenvolvimento de culturas (Aboukhaled et al., 1982). Os lisímetros se constituem o meio de maior confiança na determinação de ETc. Sua instalação e sua operação, entretanto, demandam cuidados, para que as informações obtidas sejam representativas das condições edafoclimáticas locais (Peres et al., 1992)

Silva (1996) montou e construiu um lisímetro de pesagem, baseado em célula de carga, para a determinação de evapotranspiração de referência: verificou que as mensurações diárias apresentaram uma boa concordância com os valores diários estimados pelo método de Penmam-Monteith

Bergamaschi et al. (1997) descreveram características de montagem e de operação de um lisímetro de pesagem de 3,4 metros de comprimento, 1,5 metros de largura e 0,8 metros de profundidade. Nesse tipo de sistema, o "peso" morto é contrabalenceado mecanicamente por um conjunto de alavancas e contrapesos, enquanto as variações do "peso" vivo são registradas por meio de um dinamômetro de pequena capacidade.

Os efeitos térmicos do solo podem ser minimizados pelo seu desenho. As paredes de separação entre a parte externa e interna devem ser o menos espessas possível; além disso, tais paredes devem ter o mínimo de elevação, (Gangopadhyaya et al., 1966) estabeleceram os principais cuidados na instalação de lisímetros: a) o lisímetro deve ser suficientemente grande para assegurar a sua representatividade quanto à cobertura vegetal e ao efeito de sua presença; b) as condições físicas no interior do equipamento devem ser as mesmas da área circundada; c) devem ser instalados em locais onde o efeito da advecção seja minimizado. 
No interior de estufas, a evapotranspiração é, em geral, menor que a verificada externamente, o que se atribui, basicamente, à parcial opacidade da cobertura plástica à radiação solar e à redução da ação dos ventos, os principais fatores da demanda evaporativa da atmosfera. A diferença entre a evapotranspiração interna e a externa varia de acordo com as condições meteorológicas; em geral a evapotranspiração no interior das estufas fica em torno de $60-80 \%$ da verificada no ambiente externo.

Segundo Boulard et al. (1990), os processos de evaporação e condensação tem influência direta no microclima de uma estufa e, conseqüentemente, na sua capacidade de propiciar condições satisfatórias às culturas. Fica, assim, mais importante o conhecimento das exigências hídricas das plantas, uma vez que a irrigação será a única forma de suprimento de água às culturas, e poderá afetar alguns elementos meteorológicos muito importantes. Como meio de estimar o consumo de água das culturas, lisímetros cultivados com gramíneas têm sido usados em estudos de evapotranspiração no interior de estufas plásticas.

\subsection{NECESSIDADES NUTRICIONAIS DO MELOEIRO}

A disponibilidade de nutrientes no solo, principalmente macronutrientes, é fator decisivo para a obtenção de altas produtividades do meloeiro, com frutos de boa qualidade. Em trabalhos realizados por Brantley e Warren (1961), verificou-se que a aplicação de altas doses de $\mathrm{N}$ no meloeiro provocou florescimento abundante e frutificação precoce, provocando também redução na produtividade de frutos comerciais. Resultados obtidos por Williams (1978) mostram um aumento significativo na produção de melão quando se elevou a dose de $\mathrm{N}$ para $280 \mathrm{~kg} \mathrm{ha}^{-1}$. Entretanto, para Bhella, Wilcox (1989) e Suarez (1991) o rendimento do melão decresceu com o aumento da quantidade de nitrogênio.

Sousa et al. (1998), testando doses de nitrogênio e potássio por fertirrigação na produtividade do meloeiro, concluíram que a maior produtividade comercial $\left(44,34\right.$ ton há $\left.{ }^{-1}\right)$ do meloeiro foi obtida com a combinação de $160 \mathrm{~kg}$ de $\mathrm{N} \mathrm{ha}^{-1}$ mais 
$190 \mathrm{~kg}$ de $\mathrm{K}_{2} \mathrm{O} \mathrm{ha}^{-1}$. Doses de nitrogênio e potássio superiores a $170 \mathrm{~kg} \mathrm{ha}^{-1}$ e $190 \mathrm{~kg} \mathrm{ha}^{-}$

${ }^{1}$, respectivamente, proporcionam queda na produtividade de frutos comerciais. Contudo, com $100 \mathrm{~kg}$ de $\mathrm{N} \mathrm{ha}^{-1}$, há uma tendência de aumento da produtividade com doses de $\mathrm{K}$ maiores de $190 \mathrm{~kg} \mathrm{ha}^{-1}$.

Bhella e Wilcox (1986), analisando a influencia de $\mathrm{N}$ aplicado durante o préplantio $\left(100 \mathrm{~kg} \mathrm{ha}^{-1}\right)$ via água de irrigação por gotejamento, na cultura do melão em solo de textura argilo-arenosa, concluíram que a resposta da fertirrigação na produção de frutos aumentou quando a cultura não recebeu $\mathrm{N}$ no pré plantio. Pesquisa realizada por Hernandez \& Aso (1991) mostra que a maior produtividade do meloeiro pode ser obtida com doses crescentes de nutrientes, aplicados via água de irrigação.

\subsection{A IRRIGaÇão}

A irrigação é indispensável para o meloeiro, uma vez que, pelas condições climáticas do Sudeste do país, o cultivo de algumas variedades é feito predominantemente em ambiente protegido, que além de conferir um ótimo desenvolvimento às plantas, aumenta a produtividade, com frutos de boa qualidade.

O manejo da água em culturas irrigadas tem como ponto chave decidir como, quando e quanto irrigar. A irrigação localizada, mais precisamente o gotejamento, temse mostrado um excelente método para culturas com alta sensibilidade à presença de água nas folhas e nas hastes, como é o caso do meloeiro. Para se determinar o momento da irrigação, podem-se utilizar medidas de avaliação de água no solo, como o turno de irrigação, ou considerar os sintomas de deficiência de água nas plantas (Sousa et al.,1997). Atualmente, a quantidade de água a ser aplicada é normalmente determinada pela necessidade hídrica da cultura, podendo ser estimada por intermédio da evapotranspiração, ou por meio de tensão de água no solo.

A irrigação por gotejamento tem se mostrado bastante eficiente para o aumento da produtividade na cultura do meloeiro, quando comparada a outros métodos de irrigação (Golgberg \& Shmueli, 1970; Shmueli \& Godberg, 1971). 
O manejo de água para a cultura do meloeiro é, sem dúvida, um dos aspectos que exige maiores cuidados, pois a umidade tem papel fundamental em todo o ciclo do meloeiro; nessa direção, o sistema de irrigação por gotejamento é o mais indicado, pois permite um melhor controle da quantidade de água no colo da planta e evita o aumento demasiado da umidade relativa do ar que, além de prejudicar o desenvolvimento normal da planta, favorece o aparecimento de doenças, tanto fúngicas como bacterianas. A deficiência hídrica, que se manifesta na planta de diferentes formas e intensidades, pode se tornar a principal causa no decréscimo da produtividade. Por outro lado, existem limites de umidade para o bom desenvolvimento vegetativo. A água em excesso no solo altera processos químicos e biológicos, limitando a quantidade de oxigênio e acelerando a formação de compostos tóxicos na raiz, além de causar, pela percolação intensa, a remoção de nutrientes e a inibição do crescimento normal da planta. O teor de água ideal varia de acordo com uma série de fatores, mas, principalmente, com o estádio de desenvolvimento da cultura (Brandão et al., 1998).

\subsection{A FERTIRRIGAÇÃo}

A forma tradicional de aplicação de fertilizantes nas culturas irrigadas vem sendo substituída pela fertirrigação. $\mathrm{O}$ uso deste sistema de irrigação permite a aplicação parcelada dos fertilizantes em quantas vezes forem necessárias, obedecendo às exigências da cultura, conforme as fases do seu ciclo (Sousa, 1993; Sousa et al., 1999).

A aplicação de fertilizantes simultaneamente com a água de irrigação tem grande importância tanto do ponto de vista técnico como do econômico. Essa técnica, que constitui um avanço para a agricultura irrigada, requer uma maior capacitação dos técnicos e agricultores, e seu uso está relacionado a uma série de vantagens econômicas, quando comparada aos métodos tradicionais de adubação (Vivancos, 1993).

Pode-se utilizar qualquer método ou sistema de irrigação para se aplicar fertilizantes, porém os pressurizados são os mais aconselhados (Boaz \& Halevy, 1974). Por suas características e formas de aplicação de água de forma pontual, junto à zona de 
maior concentração radicular das plantas, destaca-se a irrigação por gotejamento como a mais adequada para aplicar fertilizantes (Goldberg \& Shmuelli,1970; Sousa et al.,1993). Essas características possibilitam a aplicação de produtos, quando necessário, onde é requerido e na quantidade correta, o que permite a economia de fertilizantes e de mãode-obra, e mantém a planta em níveis ótimos de umidade e de nutrição.(Dasberg \& Bresler,1985; Frizone et al., 1986; Cuenca, 1989). Isso ocorre devido à redução das perdas dos nutrientes por lixiviação, melhorando o controle da concentração de nutrientes no solo (Bresler, 1977) e, conseqüentemente, aumentando a eficiência do uso dos fertilizantes pelas plantas (Phene et al., 1979).

O princípio de aplicação da fertirrigação preconiza o uso de fertilizantes solúveis em água e de equipamentos específicos para injetar a solução nas linhas de irrigação. Essa característica permite uma aplicação adequada e uniforme de fertilizantes com água de irrigação (Sousa \& Sousa,1993;), viabilizando o acompanhamento e o controle dos nutrientes no perfil do solo e de seus efeitos na água, no solo e na cultura. Entretanto a seleção correta dos fertilizantes é muito importante para o sucesso da fertirrigação.

O agricultor deve ter, também, os devidos cuidados na determinação das doses a aplicar, que ocorre em função das necessidades nutricionais da cultura, do conteúdo de nutrientes no solo, do histórico da área e das produtividades esperadas .(Vivancos,1993; Sousa \& Sousa,1993;). Para determinar as quantidades corretas de fertilizantes, é necessário considerar a análise do solo, da água de irrigação e foliar, bem como a extração de nutrientes pelas raízes (Raij, 1991). Porém as recomendações com base em resultados de pesquisas sobre doses de nutrientes são mais práticas.

O uso do sistema de irrigação por gotejamento superficial tem sido adotado com sucesso em vários países, à medida que problemas principais, como difícil inspeção, obstrução dos emissores por precipitados e dificuldades de manutenção, têm sido resolvidos pela melhoria dos próprios equipamentos e pela orientação técnica adequada (Phene et al., 1993; Phene et al., 1987). No Brasil esse sistema vem sendo aplicado nas culturas de alto retorno econômico, como de frutas e de hortaliça. Porém, 
espera-se uma melhor eficiência do uso da água, e poucas são as informações disponíveis a esse respeito, principalmente no tocante à prática da fertirrigação em ambiente protegido. 


\section{MATERIAL E MÉTODOS}

\section{1 ÁREA EXPERIMENTAL}

O experimento foi instalado na área experimental do Departamento de Engenharia Rural da Escola Superior de Agricultura "Luiz de Queiroz", ESALQ/USP, localizado no município de Piracicaba, São Paulo, a $22^{\circ} 42^{\prime} 30^{\prime \prime}$ de latitude sul, $47^{\circ} 30^{\prime} 00^{\prime \prime}$ de longitude a Oeste de Greenwinch e $570 \mathrm{~m}$ de altitude.

O clima, de acordo com a classificação de Köeppen, é do tipo Cwa, ou seja, clima subtropical úmido, com estiagens no inverno, com precipitação pluviométrica média de $1250 \mathrm{~mm}$, temperatura média do mês mais quente superior a $22{ }^{\circ} \mathrm{C}$ e a do mês mais frio inferior a $18{ }^{\circ} \mathrm{C}$, umidade relativa do ar média, de $74 \%$, e velocidade do vento de $\quad 2,2 \mathrm{~m} \mathrm{~s}^{-1}$, (Bezerra, 1995).

O solo utilizado no experimento foi descrito por Ranzani et al. (1966), como latossolo vermelho-amarelo, Franco Arenoso, série "sertãozinho", em nível.

\subsection{DESCRIÇÃO DAS ESTRUTURAS EXPERIMENTAIS}

O experimento foi realizado com a cultura do melão (Cucumis melo, $\mathrm{L}$,) variedade cantalupensis Naud, híbrido Don Carlos, no período de 20 de abril/2001 a 28 de julho/2001, em duas estufas de $6,30 \mathrm{~m}$ de largura, $17,50 \mathrm{~m}$ de comprimento, totalizando $220 \mathrm{~m}^{2}$ a estrutura era pré-fabricada, de aço galvanizado, com pé direito de 3,0 m e altura total igual a 4,2 m, posicionada no sentido leste-oeste. As estufas apresentavam 
cobertura com polietileno de $0,01 \mathrm{~mm}$, sombrite de $60 \%$ nas laterais e nos fundos, e com cortinas laterais PVC, de $0,15 \mathrm{~mm}$, que eram abertas pela manhã e fechadas no final da tarde e na ocorrência de chuvas, para evitar que a água atingisse as parcelas experimentais.

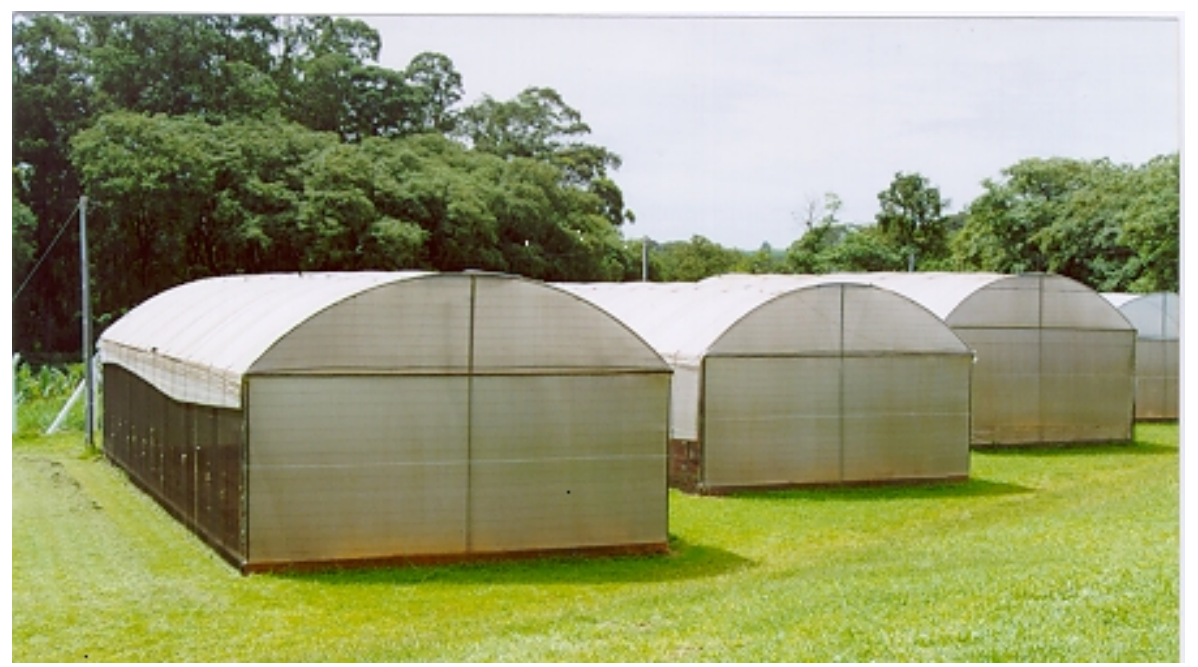

Figura 2 - Ambiente protegido do Departamento de Engenharia Rural da ESALQ/USP.

Os tratamentos foram compostos de 2 fatores

A) Níveis de irrigação: : L L $_{1}-0,50$ ETc, $\mathrm{L}_{2}-0,75 \mathrm{ETc}$, e $\mathrm{L}_{3}-1,0 \mathrm{ETc}$, da quantidade de água evapotranspirada de um lisímetro de pesagem, instalado no interior do ambiente protegido, com duas plantas de meloeiro;

B) Níveis de potássio: $\mathrm{K}_{1}-30 \mathrm{~kg}$ de $\mathrm{K}_{2} \mathrm{O} \cdot \mathrm{ha}^{-1} ; \mathrm{K}_{2}-90 \mathrm{~kg}$ de $\mathrm{K}_{2} \mathrm{O}$ ha ${ }^{-1} ; \mathrm{K}_{3}-150$ $\mathrm{kg}$ de $\mathrm{K}_{2} \mathrm{O} \mathrm{ha}^{-1} ; \mathrm{K}_{4}-210 \mathrm{~kg}$ de $\mathrm{K}_{2} \mathrm{O}$ ha. $^{-1}$, aplicados via fertirrigação, de acordo com a recomendação do Boletim 100 de adubação, feita para o meloeiro.

O delineamento estatístico adotado foi inteiramente aleatorio, com 3 repetições em esquema fatorial $3 \times 4$, resultando em 12 tratamentos. 
Nas análises estatísticas, os níveis de irrigação e as doses de potássio foram considerados fatores quantitativos e analisados pelos testes de variância, pelo teste de médias (Tukey), e pela análise de regressão.

\begin{tabular}{|l|l|l|l|l|l|}
\hline$\cdot$ & \multicolumn{5}{c|}{ Bordadura } \\
\hline K1L1 & K3L3 & K4L1 & K4L1 & K3L1 & K2L2 \\
\hline K2L2 & K3L1 & K2L3 & K1L2 & K4L2 & K2L3 \\
\hline K1L3 & K1L1 & K2L2 & K1L1 & K3L2 & K3L3 \\
\hline \multicolumn{7}{|c|}{ Bordadura } \\
\hline Legenda:
\end{tabular}

\begin{tabular}{|l|l|l|l|l|l|}
\hline$\bullet$ & \multicolumn{5}{c|}{ Bordadura } \\
\hline \\
\hline K1L3 & K4L3 & K1L2 & K4L2 & K4L2 & K4L3 • \\
\hline K2L1 & K4L1 & K1L3 & K2L3 & K2L1 & K3L2 \\
\hline K3L1 & K1L2 & K2L1 & K3L2 & K4L3 & K3L3 • \\
\hline \multicolumn{5}{|c}{ Bordadura } \\
\hline
\end{tabular}

Figura 3 - Croqui de campo dos ambientes protegidos e tratamentos.

Foram construídos cinco canteiros de $16,80 \mathrm{~m}$ de comprimento e 1,25 $\mathrm{m}$ de largura, e, aproximadamente, 0,50 $\mathrm{m}$ de profundidade, que foram divididos em 6 parcelas de 2,70 $\mathrm{m}$ de comprimento e 1,00 $\mathrm{m}$ de largura (base maior), totalizando 18 parcelas por estufa, sendo os dois canteiros das extremidades considerados como bordadura.

O plantio foi realizado em fila única de plantas, no espaçamento de 0,40 m entre elas e 1,25 m entre as filas. As parcelas experimentais foram compostas de 7 plantas, sendo 5 plantas úteis, considerando-se as 2 plantas das extremidades também como bordadura. 
Foram avaliados parâmetros durante o desenvolvimento, como consumo de água, produção, produtividade comercial, produtividade não comercial, diâmetro de frutos, comprimento dos frutos, espessura de polpa, teor de sólidos solúveis.

\subsection{PReParo do Solo, ADUbaÇÃo, TRANSPlantio das MUdAS}

Foram escavadas dez trincheiras de 16,8 $\mathrm{m}$ de comprimento, 0,6 $\mathrm{m}$ de largura, por 0,30 $\mathrm{m}$ de profundidade, e colocado posteriormente solo da estação experimental da ESALQ/USP nos dois ambientes protegidos.

Para a caracterização do solo, foram retiradas amostras de solo na camada de 0,0-0,20 m para análise química ( Tabela 2), física ( Tabela 3) e de densidade do solo (d $\left.=1,4 \mathrm{~g} \mathrm{~cm}^{-3}\right)$.

As tensões para a obtenção da curva de retenção de água foram realizadas na mesa de tensão para os pontos de 1, 3 e 6 kPa, e na câmara de Richards (Richards, 1948) para os pontos de $10,30,50,100,300$ e $1500 \mathrm{kPa}$. O ajuste da curva foi realizado de acordo com a metodologia proposta por van Genuchten (1980), descrita na equação (1), cujos parâmetros estão apresentados na Tabela 1 e foram obtidos através do programa computacional CURVARET (Dourado Neto et al., 1990) para as profundidades de 0,0 m a $0,20 \mathrm{~m}:$

Tabela 1 - Coeficientes da equação de van Genuchten.

\begin{tabular}{cc}
\hline Coeficientes & Valor \\
\hline$\alpha$ & $0,0449 \mathrm{~cm}^{-1}$ \\
coeficiente empírico $\mathrm{n}$ & 3,6737 \\
coeficiente empírico $\mathrm{m}$ & 0,1119 \\
$\left(\theta_{\mathrm{s}}\right)$ Umidade saturação do solo & $0,443 \mathrm{~cm}^{-3} \mathrm{~cm}^{-3}$ \\
$\left(\theta_{\mathrm{r}}\right)$ Umidade residual do solo & $0,162 \mathrm{~cm}^{-3} \mathrm{~cm}^{-3}$ \\
\hline
\end{tabular}


Tabela 2 - Resultados da análise de fertilidade do solo no início do período experimental. ( Macronutrientes e Micronutrientes).

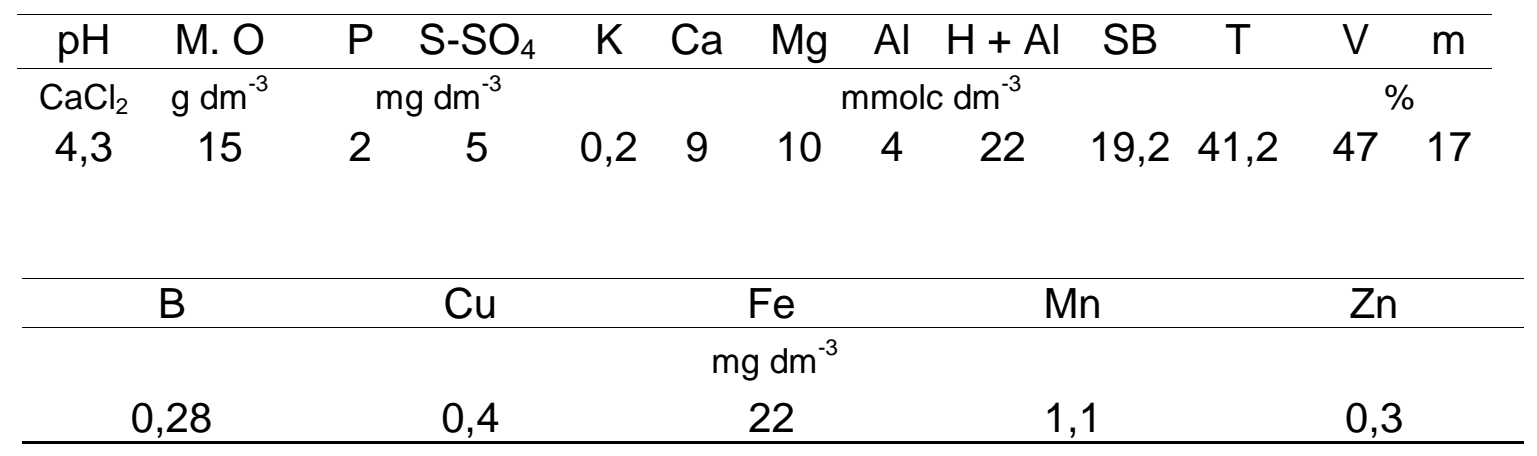

Tabela 3 - Granulometria e classe textural do solo em diferentes profundidades, no início do período experimental.

\begin{tabular}{cccc}
\hline Amostra $(\mathrm{m})$ & \% Argila & \% Silte & \% Areia \\
\hline 0,0 a 0,20 & 22,49 & 14,47 & 63,04 \\
0,20 a 0,40 & 25,82 & 13,63 & 60,55 \\
\hline
\end{tabular}

Equação de Van Genuchten ( eq 1)

$$
\theta=\theta_{\mathrm{r}} \cdot \frac{\theta_{\mathrm{s}}-\theta_{\mathrm{r}}}{\left[1+\left(\alpha \cdot\left|\psi_{\mathrm{m}}\right|\right)^{n}\right]^{n}}
$$

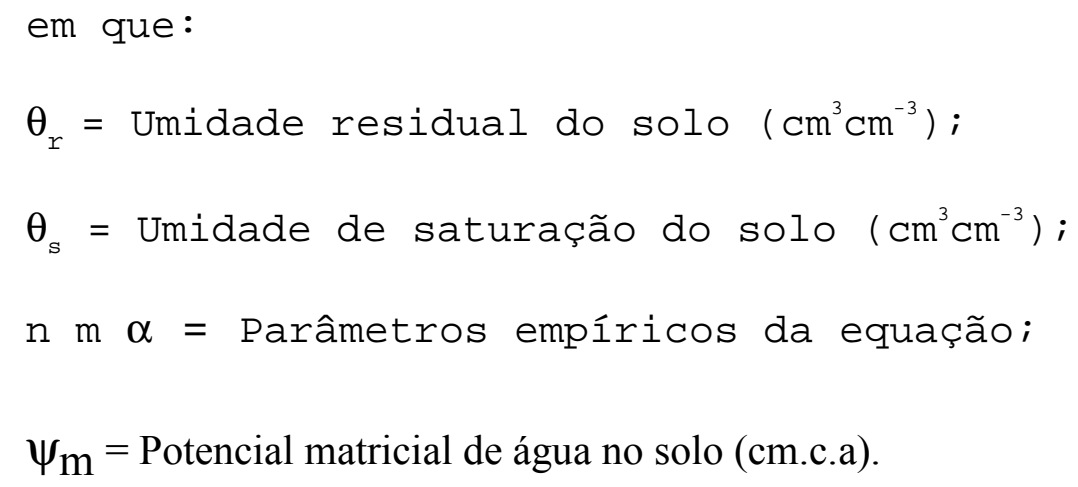


$\mathrm{Na}$ Tabela 1, estão apresentados os resultados da análise de fertilidade, cuja amostragem e cuja correção foram realizadas antes do transplantio das mudas. O solo apresentou teores baixos de todos os nutrientes e, na adubação de fundação, foram adicionados $50 \mathrm{~kg}$ de calcário dolomítico (PRNT de 67\%), e 15 dias após, $35 \mathrm{~kg}$ de termofosfato YORIN (master I), enriquecido com micronutrientes, para os dois ambientes protegidos, segundo a recomendação da análise do solo. Tais nutrientes foram incorporados com enxada rotativa posteriormente à irrigação, durante os 15 dias anteriores ao transplantio.

O transplantio das mudas foi realizado aos quinze dias após a germinação utilizando-se mudas de meloeiro, variedade. cantalupensis , cv. Don Carlos, cujo ciclo é de aproximadamente 80 dias. O potássio e o nitrogênio foram aplicados em cobertura, via água de irrigação,sendo as doses de nitrogênio a $100 \mathrm{Kg}_{\mathrm{ge} \mathrm{N}} \mathrm{ha}^{-1}$ para todos os tratamentos, o equivalente a 4,8 g por planta por ciclo.

\subsection{A IRRIGAÇÃo}

\subsubsection{MONITORAMENTO DOS ELEMENTOS CLIMÁTICOS E DA EVAPOTRANSPIRAÇÃO NO AMBIENTE PROTEGIDO.}

As condições climáticas foram monitoradas dentro da estufa durante $o$ experimento e as informações, coletadas por um sistema de aquisição de dados (datalogger) modelo CR-10, da CAMPBELL SCIENTIFIC, onde foram conectados os seguintes sensores: radiação solar global, saldo radiômetro, temperatura, umidade relativa do ar, conforme recomendação utilizada em postos meteorológicos padrão.

\subsubsection{RADIAÇÃO SOLAR GLOBAL}

A radiação solar global foi determinada por um piranômetro (LI-200X Pyranometer - LICOR Inc.), com faixa de operação de $-40^{\circ} \mathrm{C}$ a $65^{\circ} \mathrm{C}$, com erro absoluto 
máximo de $+5 \%$ e erro típico de $+3 \%$. O equipamento foi instalado a dois metros do solo, acima do dossel da cultura.

\subsubsection{SALdO DE RADIAÇÃO}

Saldo radiômetro (modelo: Q7.1 Net Radiometer-REBS; espectro: 0,25 a $60 \mu \mathrm{m}$ ) foi instalado a $1,0 \mathrm{~m}$ de altura em relação ao nível das plantas, subindo conforme o desenvolvimento da cultura.

\subsubsection{TEMPERATURA E UMIDADE RELATIVA DO AR}

A temperatura e a umidade relativa do ar foram determinadas com equipamento modelo HPM35C (R.M. Young Company), instalado também a 2 m do solo.

O sensor de temperatura, tipo $1000 \Omega$ Plantinum RTD, opera na faixa de $-50^{\circ} \mathrm{C}$ a $50^{\circ} \mathrm{C}$ e possui precisão de $\pm 0,3 \%$ a $20^{\circ} \mathrm{C}$

O sensor de umidade relativa, tipo Vaisala Intercap, opera na faixa de 0 a $100 \%$, com precisão de $2 \%$ para UR entre 0 e $90 \%$ e $3 \%$ para UR entre 90 e $100 \%$ a $20^{\circ} \mathrm{C}$.

As temperaturas obtidas internamente foram comparadas às temperaturas externas, obtidas através da estação meteorológica automática do departamento de Ciências Exatas da ESALQ/USP.

\subsubsection{FLUXO DE CALOR NO SOLO}

O medidor de fluxo de calor no solo foi instalado a $0,05 \mathrm{~m}$ de profundidade (modelo: HFT-3 Soil Heat Flux Plate).

Todos os sensores meteorológicos foram instalados no centro do ambiente protegido e o intervalo de armazenagem de dados foi de 30 minutos. 


\subsubsection{O LISÍMETRO}

A necessidade de água da cultura foi determinada através da evapotranspiração, medida em um lisímetro de pesagem com duas plantas de melão espaçadas em 0,40m; as informações foram coletadas a cada dois dias, de acordo com o turno de rega.

Esse lisímetro foi montado em um recipiente quadrado interno de $1 \mathrm{~m}^{2}$ e $0,5 \mathrm{~m}$ de profundidade, situado num recipiente quadrado externo de 1,44 $\mathrm{m}^{2}$ e 0,65 $\mathrm{m}$ de profundidade (Figura 4). Entre os recipientes, foi colocada uma estrutura metálica de sustentação e de transmissão da carga para a célula de carga HAINCO, modelo LCCA $2 \mathrm{~K}$, com capacidade máxima de $150 \mathrm{Kg}$ e precisão de $0,03 \%$ da capacidade máxima entre $-10^{\circ} \mathrm{C}$ e $40^{\circ} \mathrm{C}$

A estrutura metálica com base quadrada, de $0,40 \times 0,6 \mathrm{~m}$, foi construída com perfis tipo "U" em aço, com dois braços em forma de "V" apoiados em quatro pontos da base e convergidos para o ponto de apoio da célula de carga. Sobre os dois braços em forma de "V", foram colocados quatro parafusos com altura regulável para apoiar o recipiente interno e nivelá-lo (Figura 4).

O lisímetro foi instalado com sua face superior, $0,15 \mathrm{~m}$ abaixo do nível do canteiro, enterrando-se o recipiente externo no solo. Abaixo do lisímetro, foi instalado um tubo de drenagem da água aplicada. 

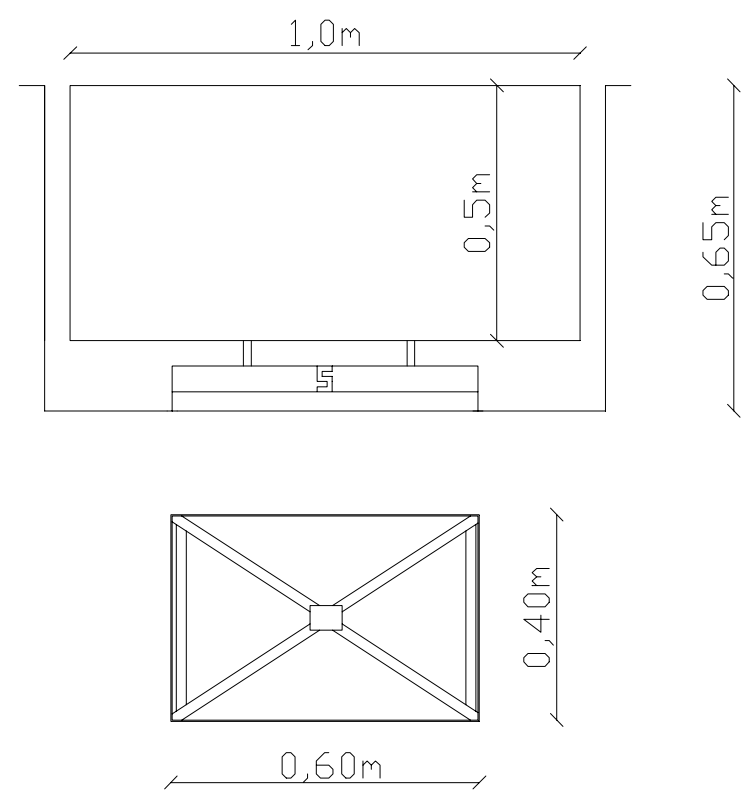

Figura 4 - Vista lateral do lisímetro e planta baixa do apoio de sustentação da célula de carga em formato "V"

A calibração do lisímetro foi feita em campo, com pequenos sacos de pedra de massa conhecida $(3,5 \mathrm{~kg}$ e $0,1 \mathrm{~kg})$, sendo colocados sobre a estrutura até um total de $36,18 \mathrm{~kg}$ e posteriormente retirados. A partir dos resultados obtidos, foi determinado um fator $(301,69)$ que transformava os sinais da célula de carga, de milivolts $(\mathrm{mV})$ para milímetros (mm).

\subsubsection{O SISTEMA DE IRRIGAÇÃO}

Foi desenvolvido um programa computacional, em ambiente DELPHI, onde se programavam os tempos de funcionamento das válvulas de irrigação para os respectivos tratamentos, possibilitando-se a automação do sistema de irrigação.

A partir desse programa computacional, instalado em um microcomputador, modelo 486, com 16 megabytes de memória, tem-se acesso à porta paralela do 
computador (saída da impressora), por onde são enviados sinais de 5 Volts a um hardware, responsável pelo acionamento das válvulas de irrigação.

As válvulas utilizadas eram da marca EMIDOL, geralmente empregadas em máquinas de lavar roupa. As linhas laterais eram de polietileno PN 30 m.c.a., com diâmetro de $13 \mathrm{~mm}$. Foi utilizado um sistema de irrigação por gotejamento, sendo os gotejadores autocompensantes nas faixas de pressão entre 0,5 e $4,0 \mathrm{kgf} \mathrm{cm}^{-2}$, modelo PCJ, de vazão de $2 \mathrm{~L} \mathrm{~h}^{-1}$, e um emissor por planta, localizado a $5 \mathrm{~cm}$ de distância do caule, dispostos nas linhas, e espaçados também em $0,40 \mathrm{~m}$. As linhas laterais tinham o comprimento máximo de 2,65 m e foram dispostas na superfície do solo.

A pressurização do sistema foi realizada com uma moto-bomba, modelo Hidrobloc C 500, com 0,5 c.v. A pessão de serviço, em todo experimento, para todos os tratamentos foi mantida a $250 \mathrm{kPa}$ por um regulador de pressão, instalado no início da linha principal e marcado por um manômetro, aferido anteriormente ao experimento.

O potencial mátrico $(\psi \mathrm{m})$ é um dos componentes do potencial total da água no solo e, reflete a energia com que a água está retida pela matriz do solo. Quanto mais úmido este estiver, maior será o valor de $\psi \mathrm{m}$, uma vez que sua variação é dada em escala negativa e o valor 0 (zero) atmosfera (atm) é o valor do potencial de água livre (solo saturado), ou seja, quanto menor a umidade do solo, mais negativo (ou menor) será o $\psi \mathrm{m}$. Para monitorar o potencial mátrico e a dinâmica de água no perfil do solo, foram instaladas doze baterias de tensiômetros dentro da área experimental, nas distâncias verticais de $0,15 \mathrm{~m}, 0,30 \mathrm{~m}, 0,50 \mathrm{~m}$, com distância radial de $0,10 \mathrm{~m}$ em relação à planta. As leituras foram feitas diariamente, às 9 horas,

A freqüência da irrigação requerida para a uma cultura, sob determinado clima, depende grandemente da quantidade de d'água que pode ser "armazenada" no solo após uma irrigação. Atualmente, não mais se procura classificar a água do solo, mas sim caracterizá-la quantitativamente, para fim de estudos, para as plantas, durante a sua movimentação pelo solo. A água disponível representa a quantidade d'água que um solo poderia reter, ou armazenar, entre a "Capacidade de campo" e o "Ponto de murcha", equivalendo às tensões de $33 \mathrm{kPa}$ a $150 \mathrm{kPa}$ (escala negativa). 
A "Capacidade de campo" descreverá a condição de movimento vertical para baixo com intensidade muito lenta, em geral atingido poucos dias após a irrigação, como apresentado por Bernardo, (1995). Para o presente trabalho, adotou-se como capacidade de campo do solo a umidade correspondente ao potencial mátrico de $-6 \mathrm{kPa}$ a $-15 \mathrm{kPa}$.

O objetivo da utilização dos tensiômetros foi avaliar a tensão de água no solo, procurando evitar valores muito elevados, que pudessem afetar o desenvolvimento da cultura, e observar a movimentação de água para baixo do sistema radicular.

\subsubsection{A FERTIRRIGAÇão}

Diferentes adubos foram dissolvidos na água de irrigação nas proporções adequadas a fim de se obter em as proporções de nutrientes exigidas pela cultura em cada fase do ciclo. As adubações com nitrogênio e potássio foram feitas através da água de irrigação, na freqüência de aplicação de 2 dias.

A adubação nitrogenada foi feita à base de nitrato de potássio $(2,97 ; 2,12 ; 1,27$; $0,425 \mathrm{~g}$ por planta de $\mathrm{N}$ via $\left.\mathrm{KNO}_{3}\right)$ e uréia, $(1,92 ; 2,66 ; 3,51 ; 4,36 \mathrm{~g}$ por planta de $\mathrm{N}$ via uréia). Em todas as fases de seu desenvolvimento, foi distribuído o equivalente a 4,8g de $\mathrm{N}$ por planta $\left(100 \mathrm{~kg}_{\text {de }} \mathrm{N} \mathrm{ha}^{-1}\right)$ para todos os tratamentos. As doses de potássio foram definidas para as três fases de desenvolvimento, segundo os tratamentos estabelecidos. Os adubos utilizados na maioria do ciclo da cultura foram o nitrato de potássio (46\% $\mathrm{K}_{2} \mathrm{O}$ e $\left.13,5 \% \mathrm{~N}\right)$ e o cloreto de potássio $\left(53 \% \mathrm{~K}_{2} \mathrm{O}\right)$; este último apenas no final da maturação, só para os tratamentos com a maior dose de potássio $\left(\mathrm{K}_{4}\right)$, devido às dificuldades de aplicação das quantidades preestabelecidas de nitrogênio e potássio para esses tratamentos.

As quantidades de nitrogênio e potássio aplicadas nas fases do ciclo do meloeiro e o parcelamento desses nutrientes durante o ciclo da cultura foram aqueles propostos por Bar-Yosef (1991), ajustados para a situação experimental. 
A aplicação foi feita através da própria moto bomba, por tanque de solução nutritiva, sendo o potássio aplicado nas seguintes doses: $\mathrm{K}_{1}-30 \mathrm{~kg}$ de $\mathrm{K}_{2} \mathrm{O} \cdot \mathrm{ha}^{-1} ; \mathrm{K}_{2}-90$ $\mathrm{kg}$ de $\mathrm{K}_{2} \mathrm{O} . \mathrm{ha}^{-1} ; \mathrm{K}_{3}-150 \mathrm{~kg}$ de $\mathrm{K}_{2} \mathrm{O} . \mathrm{ha}^{-1} ; \mathrm{K}_{4}-210 \mathrm{~kg}$ de $\mathrm{K}_{2} \mathrm{O}$.ha. ${ }^{-1}$, que é o equivalente a 1,$45 ; 4,35 ; 7,25 ; \mathrm{e} 10,14 \mathrm{~g}$ de $\mathrm{K}_{2} \mathrm{O}$ por planta por ciclo, respectivamente.

As análises da condutividade elétrica do solo foram realizadas pelo método da $\mathrm{CE}_{1: 2}$, que consiste na medida da condutividade elétrica do sobrenadante de uma solução preparada, com uma parte de solo (terra fina seca ao ar) para duas de água destilada, em base peso. Por meio da equação de regressão, citada por Silva (1998), os valores de condutividade elétrica $\mathrm{CE}_{\mathrm{ES}}$ no extrato de saturação foram estimados a partir da condutividade elétrica do sobrenadante $\mathrm{CE}_{1: 2}$.

A água utilizada nas irrigações tinha condutividade elétrica de $0,22 \mathrm{dS} . \mathrm{m}^{-1} \mathrm{e}$ pH 7,9, possuindo a seguinte composição química: $\mathrm{Na}=0,24 ; \mathrm{Ca}=0,69 ; \mathrm{Mg}=0,45 ; \mathrm{K}$ $=0,07 ; \mathrm{Cl}=0,01 ; \mathrm{SO}_{4}=0,48$ e alcalinidade $\left(2 \mathrm{CO}_{3}-2+\mathrm{HCO}_{3}-\right)=0,34 \mathrm{mmol}_{\mathrm{c}} \mathrm{L}^{-1}$.

No período compreendido entre a $1^{\mathrm{a}}$ e $3^{\mathrm{a}}$ semanas, a estimativa da quantidade de água a aplicadar ficou abaixo da real. Porém, como as plantas não apresentavam sintomas de deficiência, os níveis de adubação não foram alterados, durante o ciclo da cultura. A concentração de adubos na água foi determinada pela quantidade de fertilizantes a aplicar em cada período do ciclo de seu desenvolvimento. As quantidades aplicadas de cada fertilizante nas irrigações estão apresentadas no APÊNDICE 1.

\subsubsection{MANeJO Da CUltura}

As plantas de meloeiro, diferentemente do sistema de condução normal, a céu aberto e com crescimento rasteiro, foram transplantadas em ambiente protegido, quinze dias após a germinação das sementes. A condução da cultura foi feita com espaldeiras verticais de 1,80 $\mathrm{m}$ de altura, com dois fios de arame liso número 12, presos e esticados por mourões espaçados de 1,25 m para cada fileira de plantas. 
As plantas jovens foram tutoradas com fitilhos, instalados transversalmente aos fios de arame e presos por barbante, durante todo seu período de desenvolvimento, de tal forma que permitiram aos ramos fixarem-se nas espaldeiras de maneira ereta. As plantas foram conduzidas em haste única, retirando-se todos os brotos laterais, até o $10^{\circ}$ ou $12^{\circ}$ entrenó, com posterior tratamento fitossanitário, evitando-se a entrada de patógenos pelos ferimentos.

Após a emissão das flores, as plantas, por serem andromonóicas ( presença de flores masculinas e hermafroditas), têm a necessidade da realização de polinização manual. A polinização foi feita de maneira excessiva, para garantir um bom pegamento de frutos e boa produção por planta. A ausência de vento e a baixa população de insetos dentro do ambiente protegido fazem com que a polinização natural seja muito ineficiente, sendo necessária a intervenção humana.

O procedimento realizado nessas três ou quatro hastes secundárias foi a retirada de todos os brotos que surgiram e posterior poda uma folha após o fruto, procurando-se deixar o fruto o mais próximo possível da haste principal, polinizando-se a primeira ou segunda flor hermafrodita da haste secundária. Nos próximos entrenós continuou-se a retirada de todos os brotos, até o vigésimo entrenó, deixando-se crescer a haste secundária. A poda da planta foi realizada quando esta atingiu o arame superior. Nas hastes secundárias foi feita a poda e deixou-se crescer uma nova brotação em cada uma delas. Uma folha após o surgimento destas hastes terciárias foi feita a poda novamente, até que, a partir da hastes terciárias, deu-se o crescimento livre.

Os frutos foram recebidos em cestas de plásticos (enredados), presos à linha de arame, para ajudar a sustentação das plantas e conferir melhor qualidade à casca, permitindo o bom desenvolvimento dos frutos selecionados (raleio) ao longo do ciclo da cultura.

No decorrer do desenvolvimento da cultura foram feitas pulverizações com produtos químicos (Tabela 4), a fim de manterem-se as plantas em boas condições fitossanitarias. As capinas foram manuais e feitas apenas quando necessárias. 
Tabela 4 - Produtos químicos utilizados no decorrer do experimento

\section{Dosagem}

Grupo Químico

(em 100 litros de água)

Piramidil carbinol (Rubigan)

20 mililitros (ml)

Ditiocarbamatos (Manzate)

200 gramas $(\mathrm{g})$

Benzimidazol (Benlate)

70 gramas $(\mathrm{g})$

Nicotinoide (Mosphilam)

250 gramas $(\mathrm{g})$

O ciclo da cultura do meloeiro é de aproximadamente 80 dias e foram realizadas duas colheitas, visto que as plantas possuíam frutos mais adiantados na maturação juntamente com frutos ainda verdes. A primeira colheita ocorreu em 22/7, aproximadamente 92 dias após o transplantio (DAT) e uma semana após, em 28/7, 100 DAT, com a retirada completa de todos os frutos.

\subsubsection{Produtividade E ClassificaÇão dos Frutos}

Após cada colheita, os frutos foram classificados e a produtividade dividida em física (frutos comerciais e não comerciais) e econômica (fruto comerciais). Foram considerados frutos de valor comercial aqueles com peso acima de $600 \mathrm{~g}$ e não deformados e/ou estragados.

Os frutos de meloeiro destinados ao mercado paulista de frutas frescas devem ser classificados e embalados em caixas de $10 \mathrm{Kg}$ (Tabela 5). A classificação é feita para destinguir a qualidade dos frutos, o tamanho, a uniformidade de cor e a ausência de manchas causadas por doenças e pragas. Assim, utilizou-se a classificação do mercado atacadista da CEAGESP, apresentada por Corrêa, (2001). 
Tabela 5 - Amplitude de peso em caixa de 10kg para meloeiro.

\begin{tabular}{cccc}
\hline $\mathrm{n}^{\circ}$ de frutos & Peso minimo $(\mathrm{kg})$ & Peso maximo $(\mathrm{kg})$ & Amplitude $(\mathrm{kg})$ \\
\hline 5 & 1,85 & 2,75 & 0,9 \\
6 & 1,5 & 2,25 & 0,75 \\
7 & 1,3 & 1,95 & 0,65 \\
8 & 1,1 & 1,65 & 0,55 \\
9 & 1 & 1,5 & 0,5 \\
10 & 0,9 & 1,35 & 0,45 \\
11 & 0,8 & 1,2 & 0,4 \\
12 & 0,75 & 1,1 & 0,35 \\
13 & 0,7 & 1,05 & 0,35 \\
14 & 0,6 & 0,9 & 0,3 \\
\hline
\end{tabular}

\subsubsection{PARÂMETROS DE QUALIDADE DOS FRUTOS}

Os parâmetros médios de qualidade de frutos avaliados foram os físicos (peso médio, diâmetro e comprimento dos frutos e espessura de casca), e os químicos (sólidos solúveis totais).

Para a determinação dos parâmetros físicos, os equipamentos utilizados foram a balança de precisão $(\mathrm{g})$, e o paquímetro $(\mathrm{mm})$ enquanto para o parâmetro químico, o refratômetro ( ${ }^{\circ}$ Brix). 


\section{RESULTADOS E DISCUSSÃO}

\subsection{MANEJO da ÁGUA}

O manejo de água foi realizado com níveis de irrigação diferenciados, sendo $\mathrm{L}_{1}$, $\mathrm{L}_{2}$ e $\mathrm{L}_{3}$ equivalentes a $50 \%, 75 \%$ e $100 \%$, respectivamente, da lâmina de água consumida pelo meloeiro, determinada em um lisímetro de pesagem, instalado no centro do ambiente protegido, durante os meses de abril, maio, junho e julho, resultando na aplicação dos volumes totais de 70, 105 e 140 L por planta por ciclo (Tabela 6).

Tabela 6 - Valores mensais e totais de volume de água aplicados por meio de irrigação por gotejamento nos respectivos tratamentos.

\begin{tabular}{cccc}
\hline \multirow{2}{*}{ Meses } & \multicolumn{3}{c}{ Tratamentos - níveis de irrigação } \\
& $\mathrm{L}_{1}$ & $\mathrm{~L}_{2}$ & $\mathrm{~L}_{3}$ \\
\cline { 2 - 4 } & & Litros \\
\hline Abril (inic. 20/4) & 3,6 & 5,4 & 7,3 \\
Maio & 31,3 & 47,0 & 62,7 \\
Junho & 21,2 & 31,8 & 42,4 \\
Julho (até 20/7) & 13,6 & 20,4 & 27,3 \\
Total & 70 & 105 & 140 \\
\hline
\end{tabular}

A evapotranspiração da cultura (ETc) (figura 5) mostra o consumo de água pela planta (ETc. $<2,5 \mathrm{~L}$ por planta por dia) da fase inicial até os 30 dias após o transplantio (DAT) das mudas. A partir desse ponto, a ETc decresceu até aos 60 DAT, reduzindo-se um pouco mais até os 80 DAT, com as temperaturas mais baixas ocorridas no mês de julho. As ascensões e as reduções repentinas da ETc do meloeiro, observadas ao longo 
do tempo, podem ser atribuídas às condições climáticas e ao próprio desenvolvimento das plantas.

A variação da ETc confirma a tendência verificada no consumo de água, aumentando em meados do mês de maio e apresentando tendências de queda a partir do mês de junho e julho.

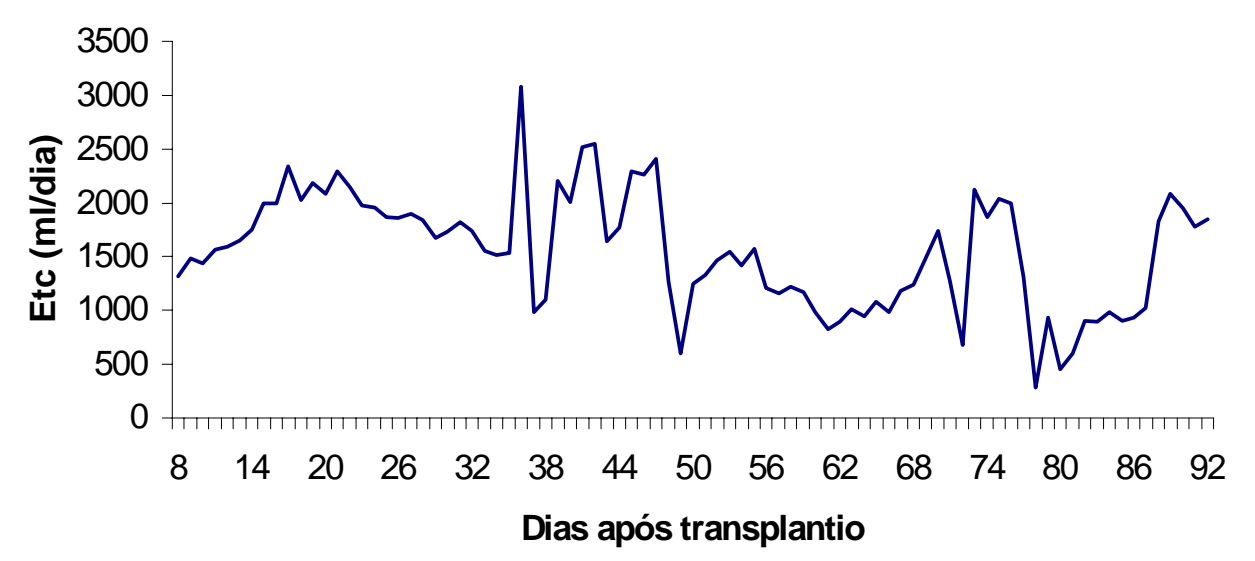

Figura 5 - Evapotranspiração do meloeiro, determinada no período de abril/2001 a julho/2001, em um lisímetro de pesagem.

A lâmina total de água aplicada, por meio da irrigação por gotejamento, do período de plantio à colheita, foi de $280 \mathrm{~mm}$ para o maior nível de água avaliado, sendo a evapotranspiração de água, nesse período, de $280 \mathrm{~mm}$. Durante o ciclo da cultura, as temperaturas do ar máximas e mínimas médias foram de 32,75 e 12,58 ${ }^{\circ} \mathrm{C}$ (Figura 6), respectivamente. 


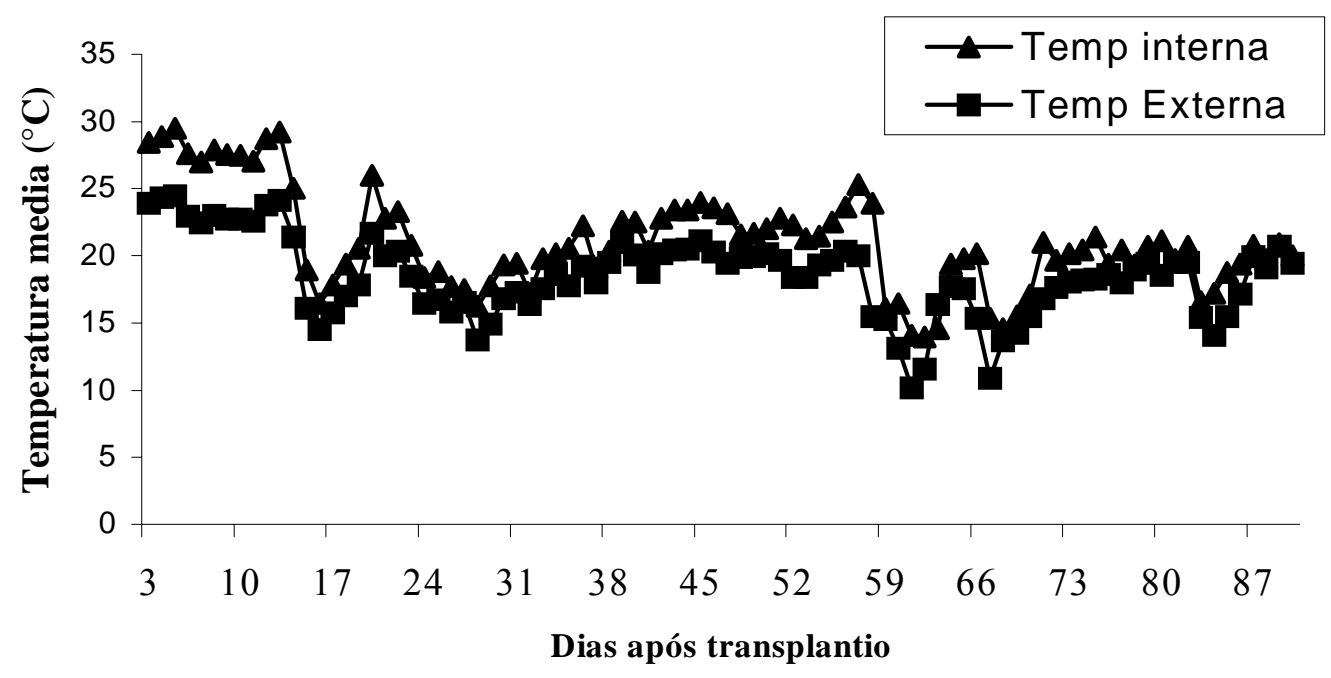

Figura 6 - Variação média da temperatura do ar interna e externa, no período experimental.

Os valores das temperaturas máximas e mínimas médias do ar foram sensivelmente superiores no interior do ambiente protegido, em relação ao ambiente externo. Segundo Siviero \& Gallerani (1993), o melão é, entre as cucurbitáceas, a mais exigente quanto a temperaturas elevadas, principalmente durante o período noturno, em que as temperaturas abaixo de $12^{\circ} \mathrm{C}$ prejudicam o seu desenvolvimento.

O baixo rendimento do meloeiro, híbrido Don Carlos, cultivado em ambiente protegido, provavelmente foi devido às baixas temperaturas ocorridas no período do experimento (20/abril/2001 a 28/julho/2001), o que resultou em um aumento do ciclo da cultura, e no número de frutos deformados e/ou fermentados, com um eventual decréscimo na produtividade total, comercial e não comercial.

Os perfis de distribuição temporal do potencial mátrico e do conteúdo de água no solo, na profundidade de 0,30m , descritos pelas Figuras 7, 8, e 9, apresentaram comportamento diferenciado na oscilação e na manutenção dos valores.

Para o nível de irrigação $\mathrm{L}_{1}$ (Figura 7), constatou-se que o potencial mátrico e a umidade do solo oscilaram entre $-72 \mathrm{kPa}$ e $-39 \mathrm{kPa}$, e $0,23 \mathrm{~cm}^{3} \mathrm{~cm}^{-3} \mathrm{e} 0,25 \mathrm{~cm}^{3} \mathrm{~cm}^{-3}$, com média de $-51 \mathrm{kPa}$ e $0,24 \mathrm{~cm}^{3} \mathrm{~cm}^{-3}$, respectivamente, entre $20 / 4$ e $20 / 7$. Os valores de 
potencial mátrico e a umidade do solo mantiveram-se acima da média, com o conteúdo de umidade do solo abaixo da capacidade de campo. Já em meados do ciclo da cultura, os valores de potencial mátrico e a umidade do solo foram muito variados, apresentando valores extremos.

Para o nível de irrigação $\mathrm{L}_{2}$ (Figura 8), constatou-se que o potencial mátrico e a umidade do solo oscilaram entre $-69 \mathrm{kPa}$ e $-36 \mathrm{kPa}$, e $0,23 \mathrm{~cm}^{3} \mathrm{~cm}^{-3} \mathrm{e} 0,25 \mathrm{~cm}^{3} \mathrm{~cm}^{-3}$, com média de $-50 \mathrm{kPa}$ e $0,24 \mathrm{~cm}^{3} \mathrm{~cm}^{-3}$, respectivamente, entre $20 / 4$ e $20 / 7$. Os valores de potencial mátrico e a umidade do solo mantiveram-se acima da média, com o conteúdo de umidade do solo abaixo da capacidade de campo . Já no final do ciclo da cultura, os valores de potencial mátrico e a umidade do solo não foram muito variados, apresentando certa constância.

O nível de irrigação $\mathrm{L}_{3}$ (Figura 9), apresentou perfil de distribuição mais constante do que $\mathrm{L}_{1}$ e $\mathrm{L}_{2}$ com apenas uma oscilação acentuada, porém bem próximo dos valores médios e abaixo da capacidade de campo, ocorrida entre o dia 26/5 e 7/6. Nesse caso, os valores de potencial mátrico e de umidade do solo variaram de $-26 \mathrm{kPa}$ a $5,45 \mathrm{kPa}$ e de $0,26 \mathrm{~cm}^{3} \mathrm{~cm}^{-3}$ a $0,35 \mathrm{~cm}^{3} \mathrm{~cm}^{-3}$ com valores médios de $-13,06 \mathrm{kPa}$ e 0,30 $\mathrm{cm}^{3} \mathrm{~cm}^{-3}$, respectivamente . Pela Figura 9, nota-se uma redução do potencial mátrico a $30 \mathrm{~cm}$ de profundidade, o que pode ser explicado pela reduzida taxa de desenvolvimento inicial observada para as plantas situadas no lisímetro. Até aproximadamente 40 dias após o transplantio, observou-se visualmente que essas plantas apresentavam porte significativamente inferior ao das demais, o que resultou na sub-estimativa das lâminas de irrigação . 


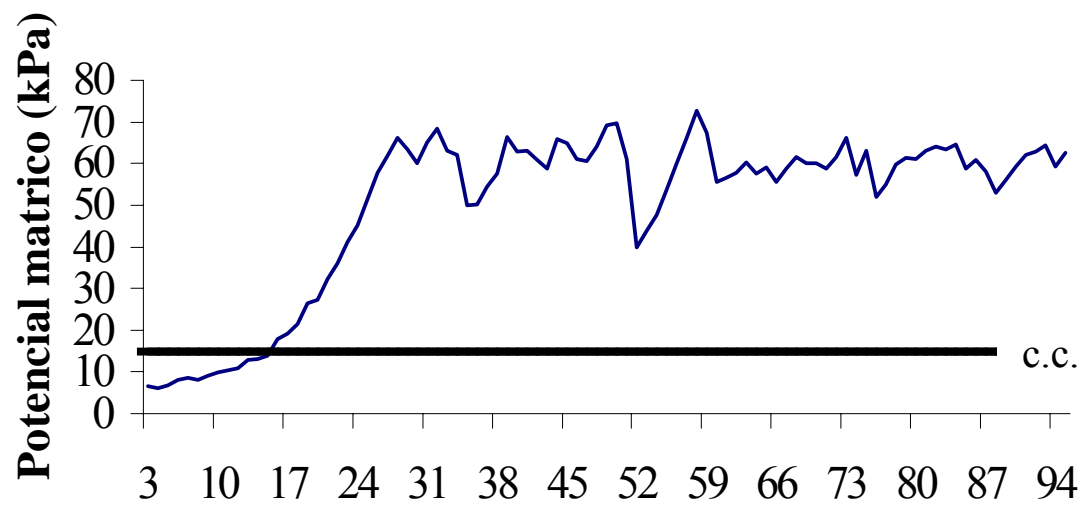

Dias após transplantio

Figura 7 - Variação do potencial matricial da água no solo para o tratamento $L_{1}$ a 0,30 $\mathrm{m}$ de profundidade nos dias após transplantio.

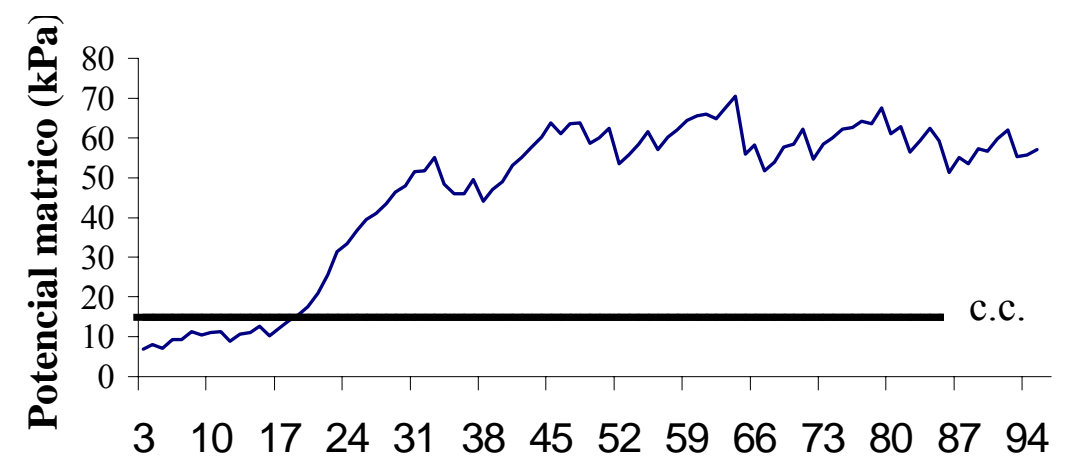

Dias após transplantio

Figura 8 - Variação do potencial matricial da água no solo para o tratamento $L_{2}$ a 0,30 $\mathrm{m}$ de profundidade nos dias após transplantio.

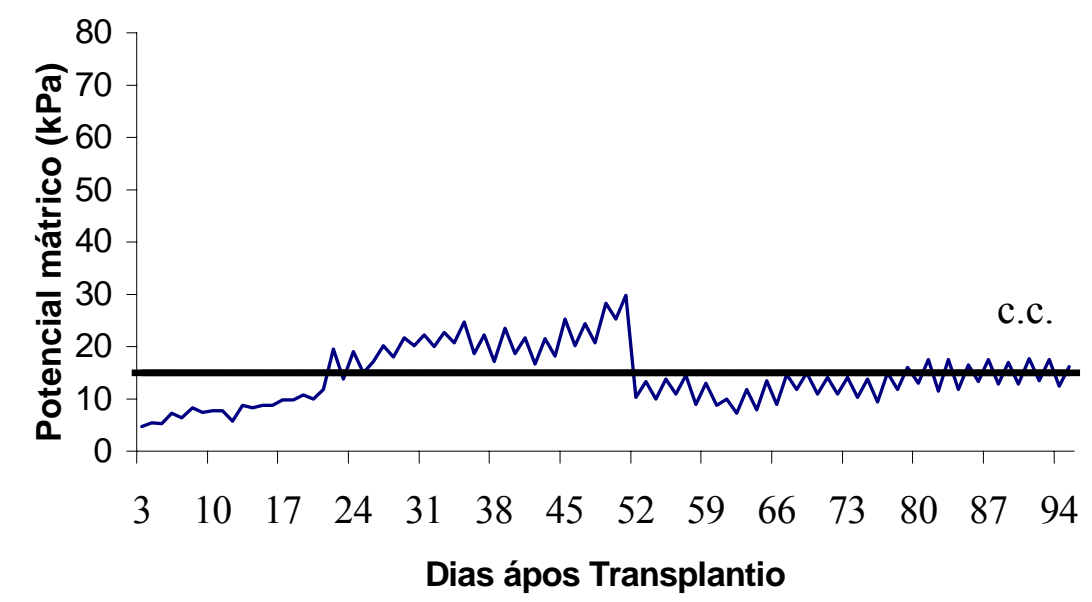

Figura 9 - Variação do potencial matricial da água no solo para o tratamento $L_{3}$ a 0,30 $\mathrm{m}$ de profundidade nos dias após transplantio. 
Após essa data, as plantas situadas no lisímetro apresentaram rápido desenvolvimento, praticamente se igualando às demais; conseqüentemente, a evapotranspiração determinada nos últimos 40 dias do ciclo foi a mais representativa da população das plantas.

\subsubsection{CONDUTIVIDADE ELÉTRICA}

A distribuição espacial da condutividade elétrica no extrato de saturação $\left(\mathrm{CE}_{\mathrm{es}}\right)$, ao final do experimento, nos tratamentos com dose de $150 \mathrm{~kg} \mathrm{~K}_{2} \mathrm{O} \mathrm{ha}^{-1}$ e nível de irrigação de $70 \mathrm{~L}$ por planta por ciclo $\left(\mathrm{K}_{3} \mathrm{~L}_{1}\right)$, mostrou os maiores valores de condutividade elétrica para as profundidades de $20 \mathrm{~cm}$ e $40 \mathrm{~cm}$; já as doses de potássio de $30 \mathrm{~kg} \mathrm{~K}_{2} \mathrm{O}$ ha $^{-1}$ e nível de irrigação de $140 \mathrm{~L}$ por planta por ciclo $\left(\mathrm{K}_{1} \mathrm{~L}_{3}\right)$ e dose de $150 \mathrm{~kg} \mathrm{~K}{ }_{2} \mathrm{O}$ ha ${ }^{-1}$ e nível de irrigação de $105 \mathrm{~L}$ por planta por ciclo $\left(\mathrm{K}_{3} \mathrm{~L}_{2}\right)$, mostraram os menores valores registrados para as profundidades amostradas, que foram $\mathrm{K}_{3} \mathrm{~L}_{1}(20 \mathrm{~cm}-$ $4,46 \mathrm{dS} \mathrm{m}^{-1}$ e $\left.40 \mathrm{~cm}-4,59 \mathrm{dS} \mathrm{m}^{-1}\right)$ e $\mathrm{K}_{1} \mathrm{~L}_{3}\left(20 \mathrm{~cm}-1,04 \mathrm{dS} \mathrm{m}^{-1}\right)$ e $\mathrm{K}_{3} \mathrm{~L}_{2}(40 \mathrm{~cm}-1,23$ $\mathrm{dS} \mathrm{m} \mathrm{m}^{-1}$ ), respectivamente (Figura 10).

Tal como foi observado na distribuição de potássio, os elevados valores de $\mathrm{CE}_{\mathrm{es}}$ verificados em $\mathrm{K}_{3} \mathrm{~L}_{1}$, podem ser atribuídos à quantidade de água aplicada nesse tratamento, que provavelmente não foi suficiente para promover a lixiviação dos ions, principalmente $\mathrm{K}^{+}$e $\mathrm{NH}_{4}{ }^{+}$, uma vez que, além do potássio $\left(\mathrm{KNO}_{3}\right)$, foi aplicado também nitrogênio na forma de uréia. Só foi aplicado cloreto de potássio (KCL) para o tratamento de $210 \mathrm{~kg} \mathrm{~K}_{2} \mathrm{O}$ ha ${ }^{-1}$ em todos os níveis de irrigação $\left(\mathrm{K}_{4} \mathrm{~L}_{3}, \mathrm{~K}_{4} \mathrm{~L}_{2}\right.$ e $\left.\mathrm{K}_{4} \mathrm{~L}_{1}\right)$, não se alterando as quantidades de sais nas amostragens de $\mathrm{CE}_{\mathrm{es}}$ para esses tratamentos. 


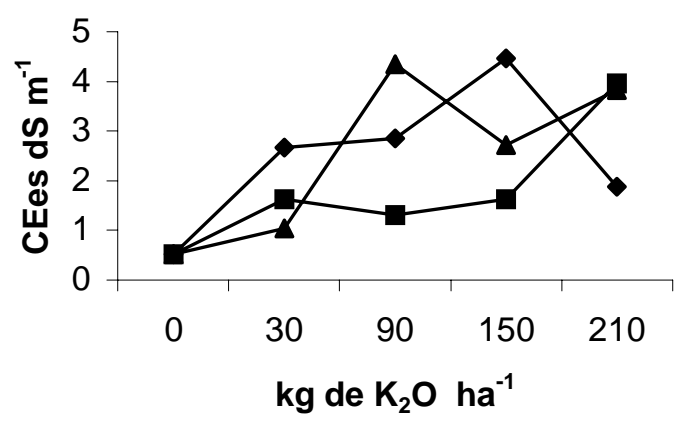

(a)

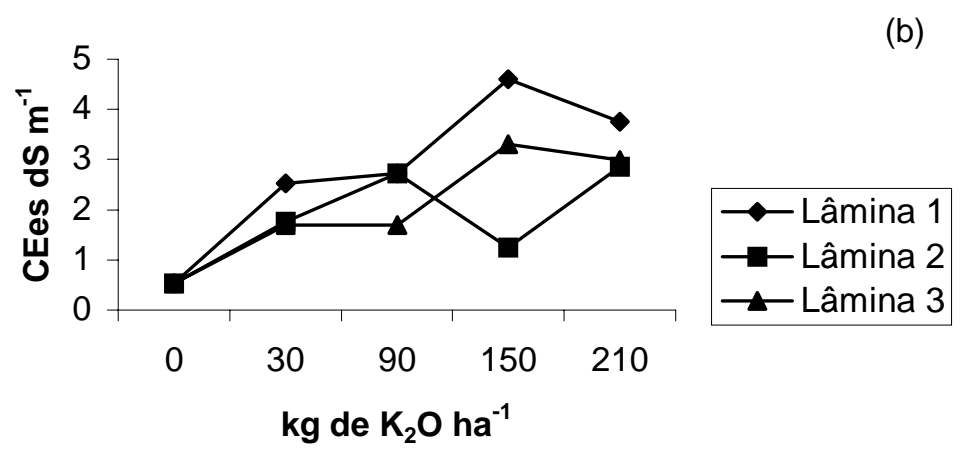

Figura 10 - Condutividade elétrica do extrato de saturação $\mathrm{CE}_{\mathrm{es}}$,para as profundidades de $20 \mathrm{~cm}$ (a) e $40 \mathrm{~cm}$ (b).

Segundo Goto, (1999), as culturas diferem pela sua capacidade de adaptação a salinidade e, em fertirrigação é sempre necessário conhecer a salinidade que produzimos, ao aplicar diferentes doses de fertilizantes, para evitar produzir um nível de salinidade que afete a produtividade da cultura. Para o meloeiro, os níveis otimos de salinidade ficam entre $2-2,6 \mathrm{dS} \mathrm{m}^{-1}$ e o valor limite onde ocorre $10 \%$ de perdas de potencial, é de $3,6 \mathrm{dS} \mathrm{m}^{-1}$, no extrato de saturação do solo.

\subsubsection{Produtividade}

Observa-se, na Figura 11, que a produtividade não comercial foi grande em todos os tratamentos, o que pode ser atribuído à prática da polinização artificial de forma 
contínua e igual para todos os tratamentos. Assim, utilizou-se a classificação do mercado atacadista da CEAGESP que comercializa frutos de melão com peso acima de $600 \mathrm{~g}$.

As maiores produtividades totais foram obtidas com as combinações de $150 \mathrm{~kg}$ $\mathrm{K}_{2} \mathrm{O} \mathrm{ha}^{-1}$ e $105 \mathrm{~L}$ por planta por ciclo e $150 \mathrm{~kg} \mathrm{~K}_{2} \mathrm{O} \mathrm{ha}^{-1}$ e $140 \mathrm{~L}$ por planta por ciclo. Já as maiores produtividades comerciais foram obtidas com as combinações $30 \mathrm{~kg} \mathrm{~K}_{2} \mathrm{O}$ ha ${ }^{-1}$ e $105 \mathrm{~L}$ por planta por ciclo e $210 \mathrm{~kg} \mathrm{~K}_{2} \mathrm{O} \mathrm{ha}^{-1}$ de potássio e $140 \mathrm{~L}$ por planta por ciclo. Nos tratamentos com doses baixas de lâmina de água $\left(\mathrm{L}_{1}\right)$ não foram registradas produtividades comerciais.

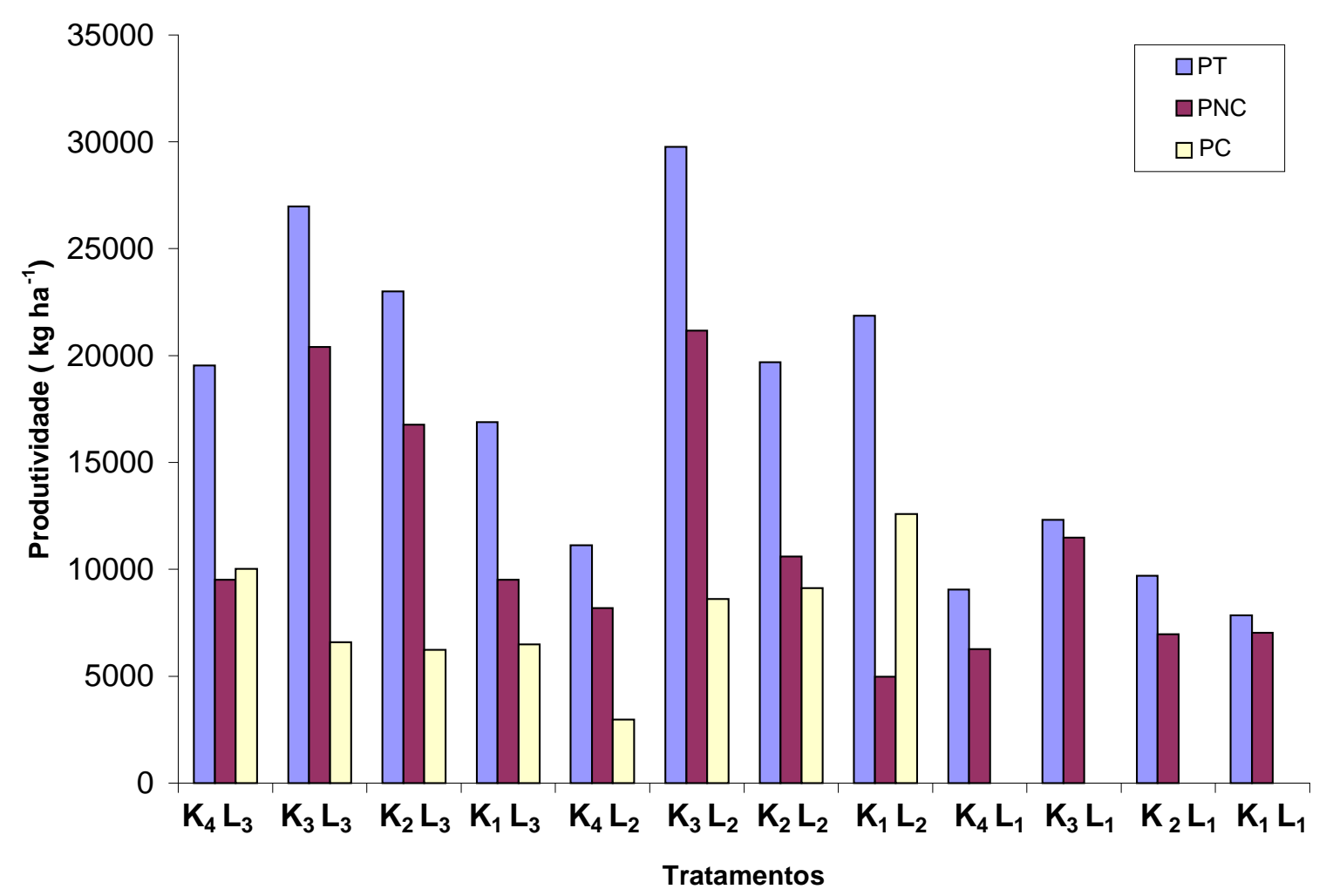

Figura 11 - Produtividade não comercial (PNC), total (PT) e comercial (PC) do meloeiro, submetido a diferentes doses de potássio e a diferentes lâminas de água. 


\subsubsection{Produtividade COMERCIAL}

A Tabela 7 apresenta a análise de variância para a produtividade comercial do meloeiro e a Tabela 6 apresenta os valores médios de produtividade comercial para os diferentes tratamentos. O nível de irrigação de 70 L.por planta por ciclo não produziu frutos comerciais com peso superior a 600 gramas, não se considerandosendo estes tratamentos na realização da análise estatística.

A produtividade comercial do meloeiro foi influenciada significativamente pelas lâminas de irrigação, pelas doses de potássio e pelo efeito interativo desses tratamentos (Tabela 7).

Tabela 7 - Análise de variância para a produtividade comercial

\begin{tabular}{lcccc}
\hline Causas da variação & Soma de Quadrados & G.L. & Quadrado Médio & F \\
\hline Lâmina (A) & 0.3668473 & 1 & 0.366847 & $4.412^{*}$ \\
Doses de K (B) & 1.8030662 & 3 & 0.601022 & $7.228^{* *}$ \\
Interação & & & & \\
(A) X (B) & 8.9642186 & 3 & 2.9880729 & $35.935^{* *}$ \\
Resíduo & 1.3304302 & 16 & 0.083151 & \\
Total (Corrigido) & 12.464562 & 23 & & \\
\hline
\end{tabular}

(*)significativo a 5\% de probabilidade; $(* *)$ significativo a $1 \%$ de probabilidade 
Tabela 8 - Valores médios de produtividade comercial de frutos de meloeiro $\left(\mathrm{t} \mathrm{ha}^{-1}\right)$, sob diferentes níveis de irrigação e diferentes doses de potássio aplicadas por fertirrigação.

\begin{tabular}{ccc}
\hline $\mathrm{K}$ & \multicolumn{2}{c}{$\begin{array}{c}\text { Níveis de Irrigação } \\
\text { (litros por planta) }\end{array}$} \\
\cline { 2 - 3 } Doses $\left(\mathrm{kg} \mathrm{ha}^{-1}\right)$ & 105 & 140 \\
\hline 30 & A 12,6 a & B 6,4 b \\
90 & B 9,1 a & B 6,2 b \\
150 & B 8,6 a & B 6,6 b \\
210 & B 2,9 b & A 10,0 b \\
\hline
\end{tabular}

Médias seguidas pela mesma letra minúscula na vertical e pela mesma letra maiúscula na horizontal não diferem estatisticamente pelo teste de Tukey, no nível de significância de 5\%.

A maior produtividade comercial média foi de $12,6 \mathrm{t} \mathrm{ha}^{-1}$, correspondente ao nível de irrigação de $105 \mathrm{~L}$ por planta por ciclo e à dose de potássio de $30 \mathrm{~kg} \mathrm{~K}_{2} \mathrm{O} \mathrm{ha}{ }^{-1}$. A menor produtividade foi de $2,9 \mathrm{t} \mathrm{ha}^{-1}$, correspondente ao tratamento com o nível de irrigação de $105 \mathrm{~L}$ por planta por ciclo e a dose de $210 \mathrm{~kg} \mathrm{~K}_{2} \mathrm{O} \mathrm{ha}{ }^{-1}$ Para os tratamentos com o nível de irrigação de $105 \mathrm{~L}$ por planta por ciclo, não houve diferença significativa entre as produções referentes às doses de potássio de 30,90 e $150 \mathrm{~kg} \mathrm{~K}_{2} \mathrm{O} \mathrm{ha}{ }^{-1}$. Para o nível de irrigação de 140 L por planta por ciclo, não houve diferença significativa entre os tratamentos com diferentes doses de potássio. Com relação às lâminas de irrigação, houve diferença significativa entre as produções somente para as doses de 30 e $210 \mathrm{~kg}$ $\mathrm{K}_{2} \mathrm{O}$ ha $^{-1}$. Não houve diferença significativa entre as produções referentes aos tratamentos com 90 e $150 \mathrm{~kg} \mathrm{~K}_{2} \mathrm{O} \mathrm{ha}^{-1}$, para as diferentes lâminas testadas.

Para o nível de irrigação de 105 L por planta por ciclo, obteve-se uma equação linear que se comportou de forma decrescente. Na Figura 12a, observa-se que a maior produtividade alcançada para esse nível de irrigação foi obtida com a menor dose de potássio avaliada, e à medida que se aumentaram as doses de potássio para a mesma quantidade de água aplicada, o potássio atuava em decréscimo na produtividade das plantas. Já para o nível de irrigação de 140 L por planta por ciclo, obteve-se uma equação linear que se comportou de forma crescente, não se percebendo a interferência 
do potássio à medida que aumenta sua dosagem para a maior quantidade de água aplicada, sendo a maior produtividade comercial obtida pela maior dose de potássio testada (Figura 12b). No entanto a maior produtividade alcançada com esse nível de irrigação foi inferior àquela obtida com o nível de irrigação de 105 L. por planta por ciclo.

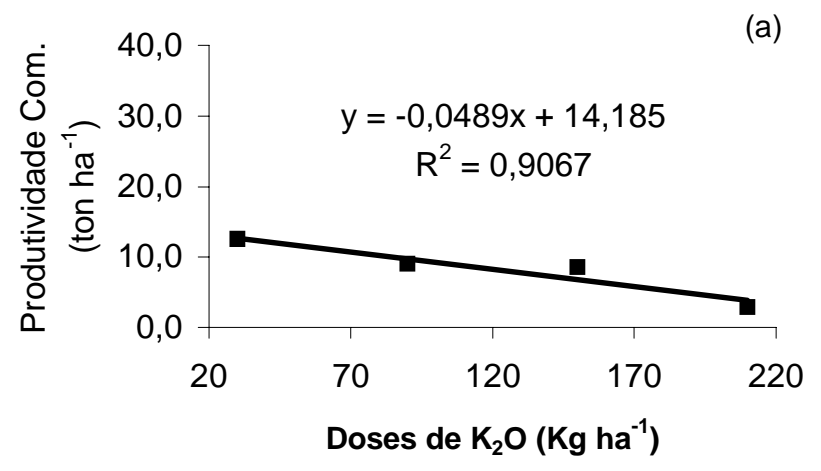

(b)

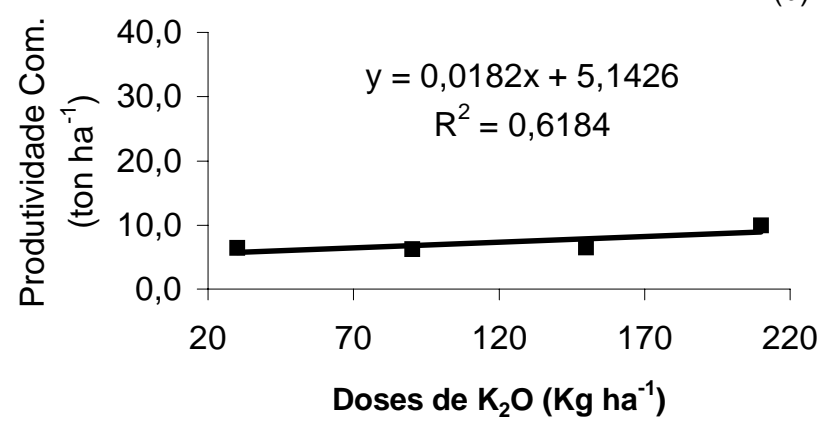

Figura 12 - Efeito da interação entre as doses de potássio aplicadas por fertirrigação e os níveis de irrigação $L_{2}$ (a) e $L_{3}(b)$, respectivamente, na produtividade do meloeiro

O potássio é absorvido da solução do solo pelas plantas na forma iônica $\left(\mathrm{K}^{+}\right)$, a qual depende da difusão do elemento através da solução do solo e, em menor proporção, do fluxo de massa (Raij, 1991). Entretanto a velocidade da difusão é influenciada pelo teor de umidade e pelo conteúdo de $\mathrm{K}^{+}$no solo, que, aumenta a concentração, seja 
naturalmente ou por meio de aplicação de fertilizantes, aumentando a velocidade de difusão de $\mathrm{K}^{+}$com a elevação da umidade do solo (Malavolta, 1981). Contrariamente aos resultados encontrados em literaturas, as maiores produtividades ocorridas no presente trabalho não ocorreram com as maiores doses de potássio e lâmina de água, provavelmente devido as baixas temperaturas ocorridas no período, que diminui o metabolismo da cultura permitindo assim, possíveis perdas de água e potássio por percolação para os tratamentos com as maiores doses. Além destes fatores poderíamos ainda, ter interferência pela disputa dos íons na solução do solo por sítios de ligação quando forem absorvidos pela planta como é o caso dos ions $\mathrm{Ca}^{+} \mathrm{e} \mathrm{K}^{+}$.

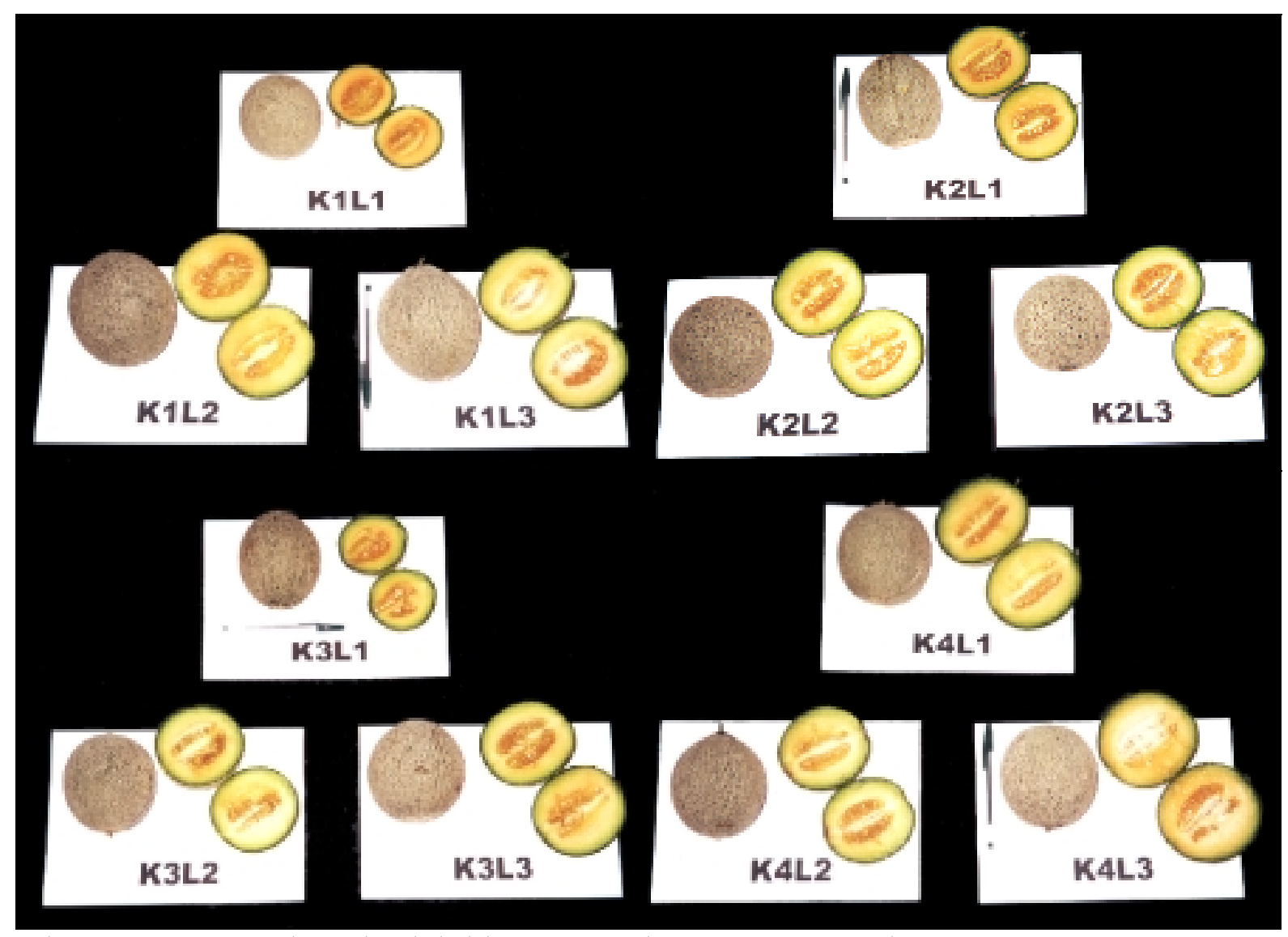

Figura 13 - Frutos de melão híbrido ‘Don Carlos' e seus respectivos tratamentos 


\subsubsection{Produtividade Não COMERCIAL}

Neste trabalho, os valores de produtividade não comercial foram altos. A interação entre as doses de potássio e os níveis de irrigação influenciaram significativamente. Houve acréscimo na produtividade não comercial do meloeiro com a diminuição nos níveis de irrigação; já para as doses de potássio, o meloeiro registrou ligeira tendência na redução desse tipo de produtividade, com o aumento da aplicação de potássio.

Tabela 9 - Análise de variância para a produtividade não comercial

\begin{tabular}{lccrc}
\hline Causas da variação & Soma de Quadrados & G.L. & Quadrado Médio & F \\
\hline Lâmina (A) & 14.030320 & 2 & 7.015160 & $107.421^{* *}$ \\
$\begin{array}{l}\text { Doses de K (B) } \\
\text { Interação }\end{array}$ & 38.567123 & 3 & 12.855708 & $196.856^{* *}$ \\
(A) X (B) & 8.9925593 & 6 & 1.4987599 & $22.950^{* *}$ \\
Resíduo & 1.5673265 & 24 & 0.065305 & \\
Total (Corrigido) & 63.157328 & 35 & & \\
\hline \multicolumn{4}{c}{$(* *)$ significativo a 1\% de probabilidade }
\end{tabular}

Tabela 10 - Produtividade não comercial do meloeiro $\left(\mathrm{t} \mathrm{ha}^{-1}\right)$ sob diferentes níveis de irrigação e diferentes doses de potássio aplicadas por fertirrigação

\begin{tabular}{|c|c|c|c|}
\hline \multirow[t]{2}{*}{$\begin{array}{c}\mathrm{K} \\
\text { Doses }\left(\mathrm{kg} \mathrm{ha}^{-1}\right)\end{array}$} & \multicolumn{3}{|c|}{$\begin{array}{l}\text { Niveis de irrigação } \\
\text { (litros por planta) }\end{array}$} \\
\hline & 70 & 105 & 140 \\
\hline 30 & B 7,0 c & C 4,9 c & A $9,5 \mathrm{c}$ \\
\hline 90 & C 6,9 c & B 10,6 b & A $16,7 b$ \\
\hline 150 & C $11,4 \mathrm{~b}$ & B $21,1 \mathrm{a}$ & B $20,4 \mathrm{a}$ \\
\hline 210 & $\mathrm{C} 6,2 \mathrm{c}$ & CB $8,1 \mathrm{~b}$ & B $9,5 \mathrm{c}$ \\
\hline
\end{tabular}

Médias seguidas pela mesma letra minúscula na vertical e pela mesma letra maiúscula na horizontal não diferem estatisticamente pelo teste de Tukey, no nível de significância de 5\%. 
A maior produtividade não comercial média foi de $21,1 \mathrm{t} \mathrm{ha}^{-1}$, correspondente ao nível de irrigação de $105 \mathrm{~L}$ por planta por ciclo e à dose de potássio de $150 \mathrm{~kg} \mathrm{~K} 2 \mathrm{O}$ $\mathrm{ha}^{-1}$. A menor produtividade foi de 4,9 $\mathrm{t} \mathrm{ha}^{-1}$, correspondente ao tratamento com nível de irrigação de $105 \mathrm{~L}$ por planta por ciclo e com dose de $30 \mathrm{~kg} \mathrm{~K}_{2} \mathrm{O} \mathrm{ha}{ }^{-1}$. Para os tratamentos com nível de irrigação de 105 L por planta por ciclo e140 L por planta por ciclo, houve diferença significativa entre as produções referentes às doses de potássio de 30, 90 e $150 \mathrm{~kg} \mathrm{~K}_{2} \mathrm{O} \mathrm{ha}{ }^{-1}$. Em relação às lâminas de irrigação, houve diferença significativa entre as produções para as doses de $30,90 \mathrm{~kg} \mathrm{~K}_{2} \mathrm{O} \mathrm{ha}{ }^{-1}$. Já para a dose de $150 \mathrm{~kg} \mathrm{~K}_{2} \mathrm{O} \mathrm{ha}{ }^{-1}$, houve diferença significativa em relação à menor lâmina de água, mas não houve diferença significativa entre a lâmina intermediária e a maior lâmina de água, as quais obtiveram as maiores produtividades não comerciais. Para a dose de $210 \mathrm{~kg}$ $\mathrm{K}_{2} \mathrm{O}$ ha $^{-1}$, a menor lâmina de água só diferenciou significativamente da maior e não houve diferença significativa em relação à lâmina de água intermediária.

A análise de regressão das doses de potássio dentro de cada nível de irrigação constatou efeitos quadráticos em $\mathrm{L}_{1} \mathrm{~L}_{2}$ e $\mathrm{L}_{3}, 70,105$ e $140 \mathrm{~L}$ por planta por ciclo. As interações entre as doses de potássio e os níveis de irrigação mostraram pontos um pouco dispersos, mas resultaram em bons coeficientes de determinação. (Figura 14).

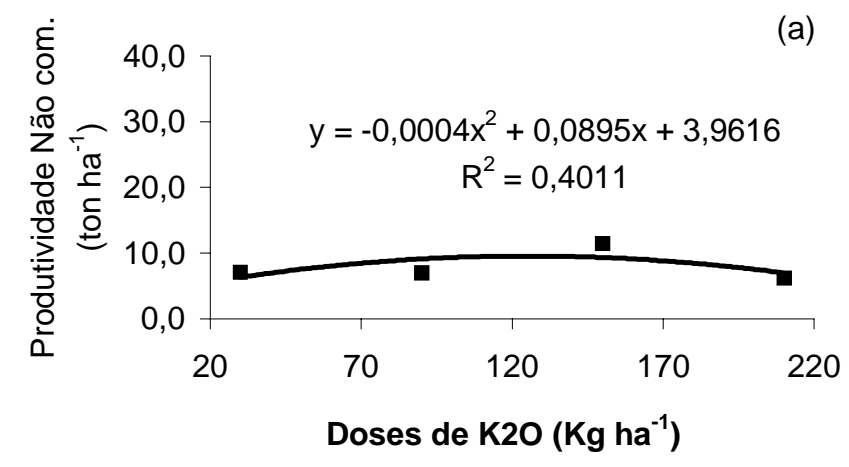



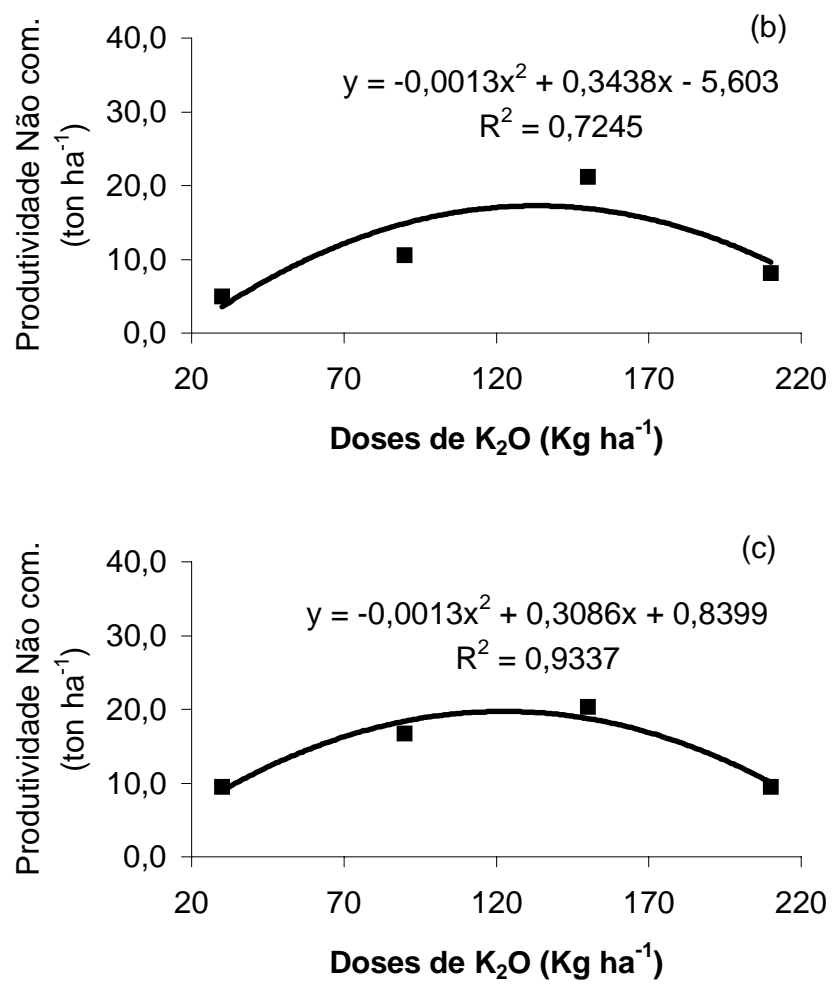

Figura 14 - Efeito da interação entre as doses de potássio aplicadas por fertirrigação e os níveis de irrigação L1(a), L2(b) e L3(c) na produtividade não comercial.

\subsubsection{Produtividade total}

A produtividade total foi uma resultante da soma das produtividades comercial e não comercial. Como a produtividade não comercial foi grande em relação à comercial, as diferenças entre as produtividades total e comercial foram bem visíveis, resultando em outro comportamento estatístico.

A análise de variância revelou efeitos significativos para as doses de potássio e para os níveis de irrigação, bem como para interação desses fatores, tal como ocorreu para a produtividade não comercial. 
Tabela 11 - Análise de variância para a produtividade total

\begin{tabular}{lcccc}
\hline Causas da variação & Soma de Quadrados & G.L. & Quadrado Médio & F \\
\hline Lâmina (A) & 65.082935 & 2 & 32.541468 & $88.938^{* *}$ \\
Doses de K (B) & 29.483192 & 3 & 9.827731 & $26.860^{* *}$ \\
Interação & & & & \\
(A) X (B) & 16.285604 & 6 & 2.7142673 & $7.418^{* *}$ \\
Resíduo & 8.7813911 & 24 & 0.365891 & \\
Total (Corrigido) & 119.63312 & 35 & & \\
& & & & \\
\hline
\end{tabular}

(**)significativo a $1 \%$ de probabilidade

Tabela 12 - Produtividade total do meloeiro $\left(\mathrm{t} \mathrm{ha}^{-1}\right)$ sob diferentes níveis de irrigação e diferentes doses de potássio aplicadas por fertirrigação

\begin{tabular}{cccc}
\hline \multirow{2}{*}{$\begin{array}{c}\mathrm{K} \\
\text { Doses }\left(\mathrm{kg} \mathrm{ha}^{-1}\right)\end{array}$} & \multicolumn{3}{c}{$\begin{array}{c}\text { Niveis de irrigação } \\
\text { (litros por planta) }\end{array}$} \\
\cline { 2 - 4 } & 70 & 105 & 140 \\
\hline 30 & B 7,8 b & A 21,8 b & A 16,8 b \\
90 & B 9,6 ab & A 19,6 b & A 23,0 ab \\
150 & B 12,3 a & A 29,7 c & A 27,0 a \\
210 & B 9,0 ab & B 11,1 a & A 19,5 b \\
\hline
\end{tabular}

Médias seguidas pela mesma letra minúscula na vertical e pela mesma letra maiúscula na horizontal não diferem estatisticamente pelo teste de Tukey, no nível de significância de 5\%.

A maior produtividade total média foi de $29,7 \mathrm{t} \mathrm{ha}^{-1}$, correspondente à lâmina de $105 \mathrm{~L}$ por planta por ciclo e à dose de potássio de $150 \mathrm{~kg} \mathrm{~K}_{2} \mathrm{O} \mathrm{ha}{ }^{-1}$. A menor produtividade foi de 9,0 $\mathrm{tha}^{-1}$, correspondente ao tratamento com nível de irrigação de $70 \mathrm{~L}$ por planta por ciclo e com dose de $30 \mathrm{~kg} \mathrm{~K}_{2} \mathrm{O} \mathrm{ha}^{-1}$ de potássio. Para os tratamentos com lâmina de $105 \mathrm{~L}$ por planta por ciclo, houve diferença significativa entre as produções referentes às doses de potássio de 30,150 e $210 \mathrm{~kg} \mathrm{~K}_{2} \mathrm{O} \mathrm{ha}^{-1}$, e não entre as doses de potássio de 90 e $150 \mathrm{~kg} \mathrm{~K}_{2} \mathrm{O} \mathrm{ha}^{-1}$. Para a lâmina de água de $140 \mathrm{~L}$ por planta por ciclo, só a dose de potássio de $150 \mathrm{~kg} \mathrm{~K}_{2} \mathrm{O}$ ha $^{-1}$ diferenciou significativamente das demais. Em relação às lâminas de água 70 e 105 L por planta por ciclo, houve diferença 
significativa entre as produções, para as doses de 30,90 e $150 \mathrm{~kg} \mathrm{~K}_{2} \mathrm{O} \mathrm{ha}^{-1}$, não havendo diferença significativa para a dose de $210 \mathrm{~kg} \mathrm{~K}_{2} \mathrm{O} \mathrm{ha}^{-1}$. Já para a lâmina de água de $105 \mathrm{e}$ $140 \mathrm{~L}$ por planta por ciclo, não houve diferença significativa entre as doses de 30, 90 e $150 \mathrm{~kg} \mathrm{~K}_{2} \mathrm{O} \mathrm{ha}^{-1}$ de potássio, mas houve diferença significativa para a dose de $210 \mathrm{~kg}$ $\mathrm{K}_{2} \mathrm{O}$ ha $^{-1}$.

Pelo teste de regressão, o efeito das doses de potássio dentro dos níveis de irrigação, foi significativo para os níveis de irrigação de 105 e 140 L por planta por ciclo, com comportamento quadrático (Figura 15), enquanto para o nível de irrigação de 70 L por planta por ciclo, a análise foi não significativa.

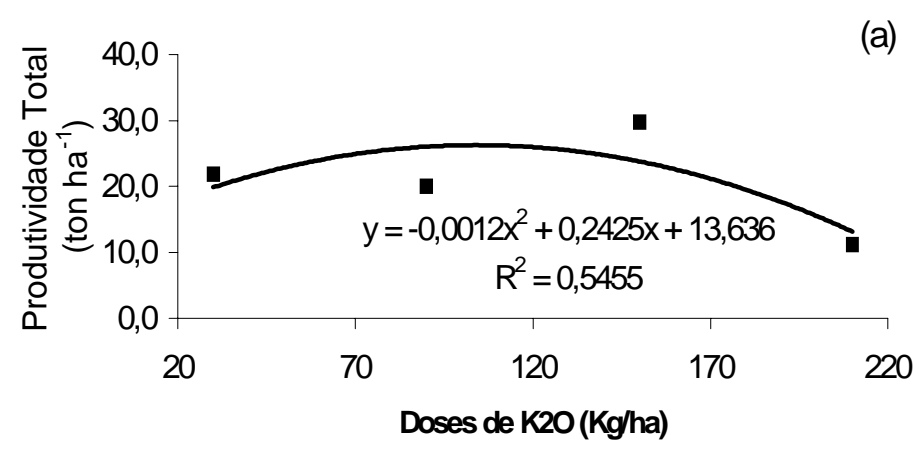

(b)

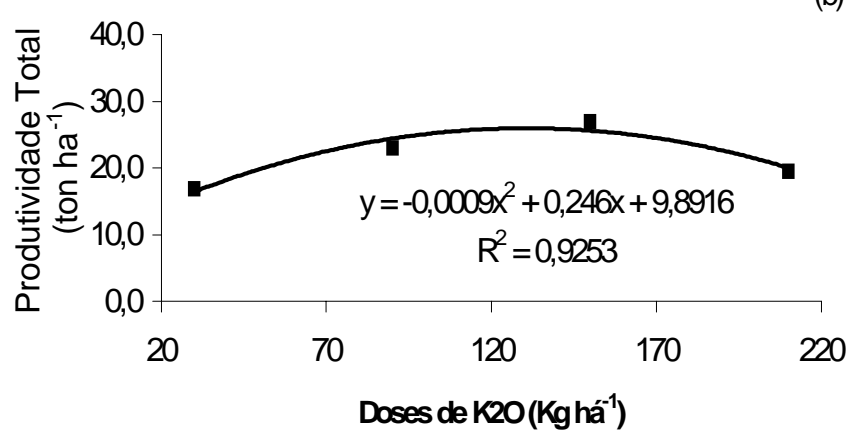

Figura 15 - Efeitos da interação entre as doses de potássio aplicadas por fertirrigação e os níveis de irrigação $L_{2}(a) L_{3}(b)$, na produtividade total do meloeiro. 


\subsection{ParÂMETRos de QUALIDADE NOS FrUtos}

As análises de fruto do meloeiro consistiram nas determinações dos parâmetros físicos (peso médio, diâmetro, altura e espessura de casca dos frutos) e químicos (sólidos solúveis totais).

\subsubsection{ParÂMETros físICOS}

\subsubsection{DIÂMETRO E COMPRIMENTO}

As dimensões dos frutos do meloeiro, como diâmetro e comprimento, são indicadores importantes na sua seleção para o mercado de frutas frescas, visto que frutos maiores são mais valorizados para o mercado interno (frutos de 1 a $2 \mathrm{Kg}$ ) enquanto o mercado de exportação prefere frutos menores (0,5 a 1 Kg), (Dusi, 1992).

A análise de variância mostrou que só a lamina de água foi significativa, para o carácter físico, (diâmetro e comprimento) (tabelas 13 e 15), sendo as doses de potássio e a interação entre os fatores não significativas.

Tabela 13 - Análise de variância para o diâmetro médio dos frutos

\begin{tabular}{lcrrr}
\hline Causas da variação & Soma de Quadrados & G.L. & Quadrado Médio & F \\
& & & & \\
\hline & 110.26991 & 2 & 55.134957 & $4.672^{*}$ \\
Lâmina (A) & 25.39990 & 3 & 8.466633 & $0.717^{\text {ns }}$ \\
Doses de K (B) & 88.819858 & 6 & 14.803310 & $1.254^{\mathrm{ns}}$ \\
Interação & 283.22161 & 24 & 11.800900 & \\
(A) X (B) & & 35 & & \\
Resíduo & 507.71128 & & & \\
Total (Corrigido) & & & & \\
\hline
\end{tabular}

(*)significativo a 5\% de probabilidade; $\left({ }^{\mathrm{ns}}\right)$ não significativo 
Os valores obtidos para o diâmetro dos frutos tiveram pequenas variações. Entretanto, considerando o efeito das lâminas de irrigação, as médias de tratamento indicaram um leve acréscimo entre as lâminas de água de 70 e $105 \mathrm{~L}$ por planta por ciclo, com prevalecimento quase constante até a lamina de água de $140 \mathrm{~L}$ por planta por ciclo (Tabela 12)

Tabela 14 - Diâmetro de frutos de meloeiro $(\mathrm{mm})$ sob diferentes níveis de irrigação e diferentes doses de potássio aplicadas por fertirrigação

\begin{tabular}{|c|c|c|c|}
\hline \multirow[t]{2}{*}{$\begin{array}{c}\mathrm{K} \\
\text { Doses }\left(\mathrm{kg} \mathrm{ha}^{-1}\right)\end{array}$} & \multicolumn{3}{|c|}{$\begin{array}{l}\text { Níveis de Irrigação } \\
\text { (litros por planta) }\end{array}$} \\
\hline & 70 & 105 & 140 \\
\hline 30 & B 90,33 b & B 95.39b & B $92.88 \mathrm{~b}$ \\
\hline 90 & B $90.30 \mathrm{~b}$ & B $94.60 \mathrm{~b}$ & B $90.80 \mathrm{~b}$ \\
\hline 150 & B $85.81 \mathrm{~b}$ & A $93.47 \mathrm{~b}$ & A $92.81 \mathrm{~b}$ \\
\hline 210 & B $91.93 \mathrm{~b}$ & B $9122 \mathrm{~b}$ & В 94.64 b \\
\hline
\end{tabular}

Médias seguidas pela mesma letra minúscula na vertical e pela mesma letra maiúscula na horizontal não diferem estatisticamente pelo teste de Tukey, no nível de significância de 5\%.

O maior valor de diâmetro médio encontrado foi de 95,39 mm, correspondente ao nível de irrigação de $105 \mathrm{~L}$ por planta por ciclo e à dose de potássio de $30 \mathrm{~kg} \mathrm{~K}_{2} \mathrm{O}$ $\mathrm{ha}^{-1}$. Para os tratamentos com níveis de irrigação de 70 e105 L por planta por ciclo, só houve diferença significativa entre as produções referentes às doses de potássio de 150 $\mathrm{kg} \mathrm{K}_{2} \mathrm{O}$ ha ${ }^{-1}$, enquanto para as outras doses não houve diferença significativa. 
Tabela 15 - Análise de variância para o comprimento médio dos frutos.

\begin{tabular}{lcrrr}
\hline Causas da variação & Soma de Quadrados & G.L. & Quadrado Médio & F \\
& & & & \\
\hline & 218.27063 & 2 & 109.13532 & $4.856^{*}$ \\
Lâmina (A) & 125.47209 & 3 & 41.82403 & $1.861^{\text {ns }}$ \\
Doses de K (B) & 105.10425 & 6 & 17.517375 & $0.780^{\text {ns }}$ \\
Interação & 539.33905 & 24 & 22.472461 & \\
(A) X (B) & 988.18602 & 35 & & \\
Resíduo & & & & \\
Total (Corrigido) & & & & \\
\hline
\end{tabular}

(*)significativo a 5\% de probabilidade; $\left({ }^{\mathrm{ns}}\right)$ não significativo

Tabela 16 - Comprimento de frutos de meloeiro $(\mathrm{mm})$ sob diferentes níveis de irrigação e diferentes doses de potássio aplicadas por fertirrigação

\begin{tabular}{cccc}
\hline \multirow{2}{*}{$\begin{array}{c}\mathrm{K} \\
\text { Doses }\left(\mathrm{kg} \mathrm{ha}^{-1}\right)\end{array}$} & \multicolumn{3}{c}{$\begin{array}{c}\text { Níveis de Irrigação } \\
\text { (litros por planta) }\end{array}$} \\
\cline { 2 - 4 } & 70 & 105 & 140 \\
\hline 30 & B 95.83 b & B 103.22 b & B 99.57 b \\
90 & B 93.12 b & B 100.22 b & B 96.65 b \\
150 & B 92.29 b & B 96.92 b & B 98.15 b \\
210 & B 97.03 b & B 98.56 b & A 105.04 b \\
\hline
\end{tabular}

Médias seguidas pela mesma letra minúscula na vertical e pela mesma letra maiúscula na horizontal não diferem estatisticamente pelo teste de Tukey, no nível de significância de 5\%.

O maior valor de comprimento médio encontrado foi de 105,04 mm, correspondente ao tratamento com nível de irrigação de 140 L por planta por ciclo e com dose de potássio de $210 \mathrm{~kg} \mathrm{~K}_{2} \mathrm{O} \mathrm{ha}^{-1}$. Para os tratamentos com níveis de irrigação de 70 e105 L por planta por ciclo não houve diferença significativa. Só houve diferença significativa entre as produções referentes à dose de $210 \mathrm{~kg} \mathrm{~K}_{2} \mathrm{O} \mathrm{ha}{ }^{-1}$, entre os níveis de irrigação de 105 e 140 L por planta por ciclo. 


\subsubsection{ESPESSURA DA POLPA}

A espessura da polpa foi influenciada significativamente por níveis de irrigação, doses de potássio, e pela interação desses fatores

Tabela 17 - Análise de variância para a espessura da polpa do meloeiro

\begin{tabular}{lcccc}
\hline & & & & \\
Causas da variação & Soma de Quadrados & G.L. & Quadrado Médio & F \\
\hline Lâmina (A) & 70.222222 & 2 & 35.111111 & $5.583^{*}$ \\
Doses de K (B) & 58.138889 & 3 & 19.379630 & $3.081^{*}$ \\
Interação & 146.44444 & 6 & 24.407407 & $3.881^{* *}$ \\
(A) X (B) & 150.94667 & 24 & 6.2894444 & \\
Resíduo & & & & \\
Total (Corrigido) & 425.75222 & 35 & & \\
\hline
\end{tabular}

probabilidade.

$(* *)$ significativo a $1 \%$ de probabilidade $(*)$ significativo a $5 \%$ de

Os tratamentos influenciaram significativamente a espessura de polpa do meloeiro e os valores encontrados estão dentro da faixa considerada ideal para a cultura, que é de $25 \mathrm{~mm}$ a $40 \mathrm{~mm}$ (cultivar valenciano amarelo). 
Tabela 18 - Espessura de polpa de frutos de meloeiro $(\mathrm{mm})$ sob diferentes níveis de irrigação e diferentes doses de potássio aplicadas por fertirrigação

\begin{tabular}{cccc}
\hline $\mathrm{K}$ & \multicolumn{3}{c}{$\begin{array}{c}\text { Niveis de Irrigação } \\
\text { (litros por planta) }\end{array}$} \\
\cline { 2 - 4 } Doses $\left(\mathrm{kg} \mathrm{ha}^{-1}\right)$ & 70 & 105 & 140 \\
\hline 30 & B 25.67 b & A 31.33 b & A 29.33 ab \\
90 & B 26.00 b & B 25.33 ab & B 24.67 b \\
150 & B 24.33 b & B 28.17 ab & B 26.67 ab \\
210 & B 24.33 b & B 24,83 b & A 33.00 a \\
\hline
\end{tabular}

Médias seguidas pela mesma letra minúscula na vertical e pela mesma letra maiúscula na horizontal não diferem estatisticamente pelo teste de Tukey, no nível de significância de $5 \%$.

Os maiores valores médios de espessura da polpa variaram de $31,33 \mathrm{~mm}\left(\mathrm{~K}_{1} \mathrm{~L}_{2}\right)$ e $33 \mathrm{~mm}\left(\mathrm{~K}_{4} \mathrm{~L}_{3}\right)$ (Tabela 18), correspondentes ao tratamento com lâmina de $105 \mathrm{~L}$ por planta por ciclo e $30 \mathrm{~kg} \mathrm{~K}_{2} \mathrm{O} \mathrm{ha}^{-1}$ e com lâmina de $140 \mathrm{~L}$ por planta por ciclo e $210 \mathrm{~kg}$ $\mathrm{K}_{2} \mathrm{O}$ ha $^{-1}$, respectivamente. Em termos médios, o aumento das doses de potássio não mostrou uma tendência clara na obtenção de frutos com polpa mais espessa. Entretanto, esse comportamento foi significativo para os níveis de irrigação de 105 e 140 L por planta por ciclo para a dose de potássio de $30 \mathrm{~kg} \mathrm{~K}_{2} \mathrm{O} \mathrm{ha}^{-1}$, havendo os valores médios oscilado muito pouco e sendo os valores da espessura de polpa não muito menores do que os dos melhores tratamentos. Para a dose de potássio de $210 \mathrm{~kg} \mathrm{~K}_{2} \mathrm{O} \mathrm{ha}{ }^{-1}$, houve diferença significativa entre as lâminas de irrigação de 105 e 140 L por planta por ciclo.

\subsubsection{PARÂMeTros QUímicos}

\subsubsection{SÓLIDOS SOLÚVEIS TOTAIS}

A análise de variância foi significativa para o fator lâmina de água, enquanto, para doses de potássio e a interação entre os fatores, não apresentou significância. 
Tabela 19 - Análise de variância para o teor de sólidos solúveis totais.

\begin{tabular}{lcccc}
\hline Causas da variação & Soma de Quadrados & G.L. & Quadrado Médio & F \\
\hline Lâmina (A) & 10.597222 & 2 & 5.2986111 & $4.436^{*}$ \\
Doses de K (B) & 10.250000 & 3 & 3.4166667 & $2.860^{\text {ns }}$ \\
Interação & & & & \\
(A) X (B) & 4.7916667 & 6 & 0.7986111 & $0.669^{\text {ns }}$ \\
Resíduo & 28.666667 & 24 & 1.1944444 & \\
Total (Corrigido) & 54.305556 & 35 & & \\
& & & & \\
\hline
\end{tabular}

$(*)$ significativo a $5 \%$ de probabilidade; $\left({ }^{\mathrm{ns}}\right)$ não significativo

Tabela 20 - Valores médios de sólidos solúveis totais $\left({ }^{\circ}\right.$ Brix) de frutos de meloeiro sob diferentes níveis de irrigação e diferentes doses de potássio aplicadas por fertirrigação

\begin{tabular}{cccc}
\hline \multirow{2}{*}{$\begin{array}{c}\mathrm{K} \\
\text { Doses }\left(\mathrm{kg} \mathrm{ha}^{-1}\right)\end{array}$} & \multicolumn{3}{c}{$\begin{array}{c}\text { Níveis de irrigação } \\
\text { (litros por planta) }\end{array}$} \\
\cline { 2 - 4 } & 70 & 105 & 140 \\
\hline 30 & B $11.33 \mathrm{~b}$ & B $10.67 \mathrm{~b}$ & B $11.50 \mathrm{~b}$ \\
90 & B $9.83 \mathrm{~b}$ & B $10.17 \mathrm{~b}$ & B $11.00 \mathrm{~b}$ \\
150 & B $11.17 \mathrm{~b}$ & B $11.50 \mathrm{~b}$ & A $12.83 \mathrm{~b}$ \\
210 & B $11.50 \mathrm{~b}$ & B $10.00 \mathrm{~b}$ & B $12.16 \mathrm{~b}$ \\
\hline
\end{tabular}

Médias seguidas pela mesma letra minúscula na vertical e pela mesma letra maiúscula na horizontal não diferem estatisticamente pelo teste de Tukey, no nível de significância de 5\%.

Os teores de sólidos solúveis encontrados no melão são praticamente iguais aos teores de sólidos solúveis produzidos nos melões do Brasil. Esses dados aproximam-se dos valores encontrados por Prabhakar et al. (1985).

Os valores médios de sólidos solúveis totais $\left({ }^{\circ} \mathrm{Brix}\right)$ de frutos variaram de 12,8 a 9,8 ${ }^{\circ}$ Brix para as combinações $\mathrm{K}_{3} \mathrm{~L}_{3}$ e $\mathrm{K}_{2} \mathrm{~L}_{1}$, correspondente à lâmina de água de $140 \mathrm{~L}$ por planta por ciclo, e às doses de $150 \mathrm{~kg} \mathrm{~K}_{2} \mathrm{O}$ ha $^{-1}$ e à lâmina de água de $70 \mathrm{~L}$ por planta por ciclo e à dose de $90 \mathrm{~kg}$ de $\mathrm{K}_{2} \mathrm{O}$ há ${ }^{-1}$, respectivamente (Tabela 20). 
As doses de potássio não apresentaram uma tendência muito definida, sendo a análise não significativa para as doses de potássio; já para os níveis de irrigação, o aumento da quantidade de água aplicada para a dose de potássio de $150 \mathrm{~kg} \mathrm{ha}^{-1}$ promoveu elevação do ${ }^{\circ}$ Brix, com a aplicação de 140 L por planta por ciclo, apresentando uma diferença significativa.

O potássio atua no peso dos frutos, em virtude de seu papel na translocação de carboidratos (Farias, 1990; Katayama, 1993), tendo, também, um papel importante no conteúdo de sólidos solúveis dos frutos. No caso do meloeiro, autores como Srinivas \& Prabhakar (1984) mencionam a importância desse elemento no ${ }^{\circ}$ Brix dos frutos dessa cultura e observaram efeitos significativos no conteúdo de sólidos solúveis de frutos de melão, quando compararam colheitas em outras épocas do ano, cuja disponibilidade hídrica e temperatura variam entre alta e moderada.

Não foi observado, no presente trabalho, o aumento do conteúdo de sólidos solúveis nos tratamentos sujeitos às menores lâminas de água, convergindo, assim, para os resultados obtidos por Buzeti et al. (1993) e Pinto et al. (1995). 


\section{CONCLUSÕES}

A partir dos resultados obtidos no presente trabalho, podem-se estabelecer as seguintes conclusões:

As maiores produtividades totais foram $\left(29,7\right.$ e 27 ton $\left.\mathrm{ha}^{-1}\right)$ obtidas com as combinações de $150 \mathrm{~kg} \mathrm{~K}_{2} \mathrm{O}$ há $^{-1}$ e $105 \mathrm{~L}$ por planta por ciclo e $150 \mathrm{~kg} \mathrm{~K}_{2} \mathrm{O} \mathrm{ha}^{-1}$ e 140 L por planta por ciclo, respectivamente;

Já as maiores produtividades comerciais foram (12,6 e 10 ton $\left.\mathrm{ha}^{-1}\right)$ obtidas com as combinações $30 \mathrm{~kg} \mathrm{~K}_{2} \mathrm{O} \mathrm{ha}{ }^{-1}$ e $105 \mathrm{~L}$ por planta por ciclo e $210 \mathrm{~kg} \mathrm{~K}_{2} \mathrm{O} \mathrm{ha}^{-1}$ e 140 L por planta por ciclo;

Para o menor nível de irrigação (70 L por planta por ciclo) não houve produção de frutos comerciais, e quando combinado com altas doses de potássio (150 e $210 \mathrm{~kg}$ $\mathrm{K}_{2} \mathrm{O}$ há $^{-1}$ ) resultaram nos maiores níveis de salinidade, acima dos tolerados pela cultura, em todas as profundidades estudadas.

Verificou-se uma redução acentuada na produtividade comercial, ocasionando provavelmente devido as baixas temperaturas ocorridas no período experimental nas condições de Piracicaba-SP, visto que a maioria das cucurbitáceas são sensíveis as baixas temperaturas. 


\section{REFERÊNCIAS BIBLIOGRÁFICAS}

ABOUKHALED,A.; ALFARO,A.; SMITH,M. Lysimeter. Rome, FAO, 1982. 68p. (Irrigation and Drainage Paper, 39).

ARAÚJO, J. P. Cultura do melão. Petrolina: EMBRAPA, CPATSA, 1980. 40p.

BAR-YOSEF, B. Fertilization under drip irrigation. In: PALGRAVE, D.A. (Ed.) Fluid fertilizer: science and technology. Ney York: Marcel Dekker,1991. cap. 14, p.285-329.

BERGAMASCHI,H.; SANTOS,M.L.V.; MEDEIROS,S.L.P.; CUNHA,G.R.; Instalação e uso de um lisímetro de balança no Estado do Rio Grande do Sul, Brasil. In: CONGRESSO BRASILEIRO DE AGROMETEOROLOGIA, 7., Viçosa, 1991. Resumos. Viçpsa: SBA, 1991. p.176-177.

BERNARDO, S. Manual de irrigação. 6.ed. Viçosa: Imprensa Universitária, 1995. $657 \mathrm{p}$.

BHELLA, H. S., WILCOX, G. E. Yield and composition of muskmelon as influenced by preplant and trickle applied nitrogen. Hortscience, v.21, n.1, p.86-88, 1986.

BHELLA, H.S., WILCOX, G.E. Yeld and composition of muskmelon as influencied by preplant and trickle applied nitrogen. Hortscience, v.21, n1,p.86-88,1989.

BOAZ, M; HALEVY, I. Trickle irrigation. Jerusalem: Ministry of Agriculture,New Letter Israel Agriculture, 1974. p.39-57. 
BRANDÃO FILHO, J.U.T.;VASCONCELLOS, M.A.S. A Cultura do meloeiro. In: GOTO, R.;TIVELLI, S.W. (Ed). Produção de hortaliças em ambiente protegido: condições subtropicais. São Paulo: Fundação Editora da UNESP,1998. cap. 6, p.161-193.

BRANTLEY, B. B.;WARREN, G. F. Effect of nitrogen nutrition on flowering fruiting and quality in the muskmelon. Proceedings of American Society for Horticultural Science, v.77, p.424-431, 1961.

BRESLER, E. Trickle-drip irrigation: principles and application to soil water management. Advances in Agronomy, v. 29, p.344-396, 1977.

BUZETI, S.; HERNANDES, F. B. T.; SÁ, M. E. Influencia da adubação nitrogenada e potássica na influencia da do uso da água e na qualidade de frutos de melão. Scientia Agricola, v.50, n.2, 1993. 419-426p.

CAMARGO, A. P.; SENTELHAS, P.C. Avaliação do desempenho de diferentes métodos de estimativa da evapotranspiração potencial no Estado de São Paulo. Revista Brasileira de Agrometeorologia, v. 5. n. 1. p.89-97, 1997.

CHANG, J. Climate and agriculture: an ecological: an ecological survey. Chicago: Aldine Publ., 1968. 304p.

CORRÊA, G. A. F. S. Elaboração da norma de classificação do melão (Cucumis melo L.) para o programa paulista para melhoria dos padrões comerciais e embalagens de hortifrutigrangeiros. Piracicaba, 2001. 33p. Relatório (Estagio Profissionalizante) Escola Superior de Agricultura "Luiz de Queiroz" , Universidade de São Paulo

CUENCA, R. H. Irrigation system desing, an engineering approach. New Jersey: Oregon State University, Department of Agricultural Engineering; 1989. p.346-350.

DASBERG, S; BRESLE, E. Drip irrigation nanual. Logan: International Irrigation Information Center, 1985. 95p. 
DIAS, R. C. S; COSTA, N. D; CERDAN, C; SOLVA, P. C. G; QUEIROZ, M. A; ZUZA, F; LEITE, L. A. S; PESSOA, P. F. A. P; TERAO, D. A cadeia produtiva do melão no nordeste. Petrolina: EMBRAPA, CPATSA, 1997. 73p.

DOURADO NETO, D; JONG van LIER, K.; BOTREL, T. A; LIBARDI, P. L; Programa para confecção da curva de retenção da água do solo, utilizando modelo de Van Genuchten. Engenharia Rural, v.1, n.2, p.92-102, 1990.

DUSI, A. N. Melão para exportação: aspectos técnicos da produção. Brasília: DENACOOP, 1992. 38p. (FRUPEX, 1)

FARIA, C. M. B. Nutrição mineral e adubação de melão. Petrolina: EMBRAPA, CPATSA, 1990. 26p. (Circular Técnica, 22)

FILGUEIRA, F. A . R. Manual de olericultura: cultura e comercialização de hortaliças. 2. ed. São Paulo: Agronômica Ceres, 1981. v. 1, 338p.

FNP CONSULTORIA \& COMERCIO: Agrianual 2000 anuário estatístico da agricultura brasileira. São Paulo, 1999. 485p.

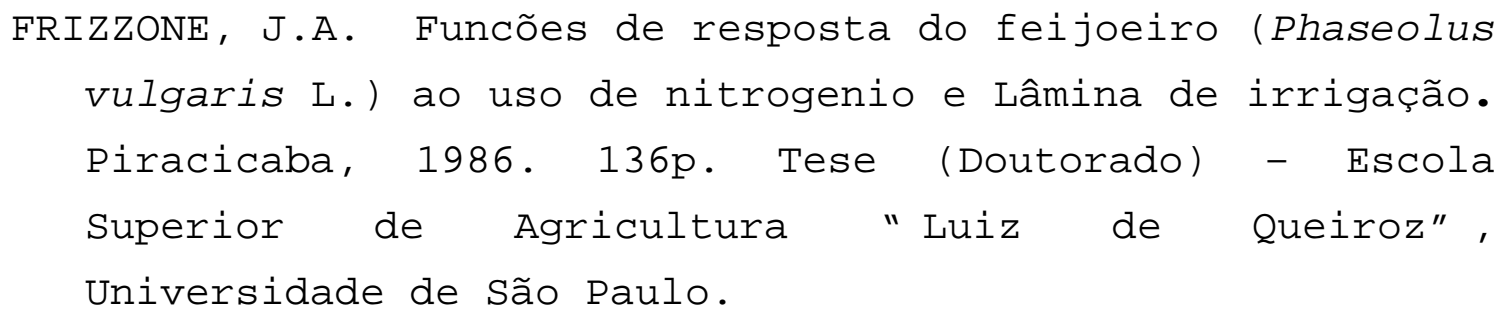

FRIZZONE, J.A.; BOTREL, T.A.; DOURADO NETO, D. Aplicação de fertilizantes

via água de irrigação. Piracicaba: ESALQ/DER, 1994. 35p. (Série Didática, 8)

FRIZZONE, J. A; FOlEGATtI, M. V; BAStOS, E. A; COELHO, E. F. Doses de nitrogênio e potássio por fertirrigação na produtividade do meloeiro. In; BALBUENA, R. H; BENEZ, S. H. JORAJURIA, D. Avances en el manejo del suelo y água en la Ingenieria rural latinoamericana. La Plata: Editorial de la U.N.L.P. 1998, p.195-200. 
GATES, D. M; PAPAIN, L. E. Atlas of energy budgets of plants leaves. New York: Academic Press, 1971

GOLBERG, D.; SHMUELI, M. Drip irrigation: a method used under arid desert conditions of high water and soil salinity. Transaction of the ASAE, v.13, n.1, p.38-41, 1970 .

GOTO, R. Plasticultura nos trópicos: uma avaliação técnicoeconômica. Horticultura Brasileira, v.15, p.163-165, 1997. Suplemento.

GOTO, W. S.; fertirrigação com produtos ultrasoluveis In: FOLEGATTI, M.V. (Coord.) Fertirrigação: citrus, flores, hortaliças. Guaíba: Agropecuária, 1999. cap.1, p.155-169.

HERNANDEZ, C. F.; ASO, P. J. Fertilización del melón en invernadero. Avance Agroindustrial, n.47, p.3-4, 1991.

JOLLIET, O. Hortitrans, a model for predicting and optimizing humidity and transpiration in greenhouses. Journal of Agricultural Engineering Resources, V. 57. p.23-37, 1994 .

JOLY, A. B. "Botânica" introdução a taxonomia vegetal. São Paulo: Editora Nacional, 1993. v. 4, 776p. (Biblioteca Universitária Ciências Puras, 3).

JONES, H. G. Plants and microclimate. 2.ed. Cambridge: Cambridge University Press, 1992. 428p.

KATAYAMA, M.; Nutrição e adubação mineral de melão e melancia. In: SIMPOSIO SOBRE NUTRIÇÃO E ADUBAÇÃO DE HORTALIÇAS, Jaboticabal, 1990, Anais. Piracicaba: Associação Brasileira de Pesquisa da Potassa e do Fosfato, 1993. p.219-226.

LOZZADA, B; ANGELOCCI, L.R. Determinação da temperatura base a de graus-dia na estimativa da duração dos 
subperíodos de desenvolvimento do milho. in: CONGRESSO BRASILEIRO DE AGROMETEOROLOGIA, 10., Piracicaba, 1997: Anais. Piracicaba: SBA, 1997. p.9-11.

MALAVOLTA, E. Manual de química agricola: nutrição de plantas e fertilidade dos solos. São Paulo: Agronômica Ceres, 1976. 538p.

MALAVOLTA, E. Elementos de nutricão mineral em plantas. São Paulo: Agronômica Ceres, 1980. 281p.

MALAVOLTA, E. Manual de química agricola: adubos e adubações . São Paulo: Agronômica Ceres, 1981. 596p.

PEREIRA, J. A. Apontamentos da diciplina LFM 594. analise física do ambiente. Piracicaba: ESALQ, Departamento de Física e Meteorologia, 1995. 5p.

PEREIRA, J.A.; VILLA NOVA, N.A.; SEDIYAMA, G.C. Evapo (transpi) ração.

Piracicaba: FEALQ, 1997. 183p.

PERES, J. G.; SCARDUA, R. Estudo de métodos agroclimatológicos para estimativa da evapotranspiração potencial de referência (ETo), segundo Doorenbos \& Pruitt. Engenharia Rural, v.2, n.2, p.48-63, 1991.

PERES, J. G.; SCARDUA, R.; VILLA NOVA, N. A. Coeficiente de cultura (kc) para cana-de-açúcar: ciclo de cana-soca. Açúcar \& Álcool, n.62, p.34-41, 1992.

PEZZOPANE, J, R. Mi MORAES, A V. C; PICINI, A. E.. Determinação da temperatura base para capim elefante. in: CONGRESSO BRASILEIRO DE AGROMETEOROLOGIA, 10., Piracicaba, 1997. Anais. Piracicaba: SBA, 1997, p.61-63.

PHENE, C. J.; DETAC, W. R.; CLARK, D. A. Real-time irrigation scheduling of cotton with an automated pan evaporation system. Applied Engineering in Agriculture, n.5,v.8, p.787-793, 1993. 
PHENE, C. J.; DAVIS, K. R.; HUTMACHEC, R. B.; MECORMICK, R. L. Advantages subsurface regation for processing tomatoes. Acta Horticulturae. n. 200, p.101114, 1987.

PINTO, J.M. Aplicação de dioxido de carbono via água de irrigação em meloeiro. Piracicaba, 1997. 82p. Tese (Doutorado)- Escola Superior de Agricultura “Luiz de Queiroz”, Universidade de São Paulo.

PINTO， J.M.; SOARES， J.M.; CHOUDHURY, E.N.; PEREIRA， J.R. Adubação via água de irrigação na cultura do melão. Pesquisa Agropecuária Brasileira, v.28, n.11, p.1263-1268, 1993.

PINTO, J.M.; SOARES, J.M.;COSTA, N. D.; BRITO, L. T. L.; PEREIRA, J. R. Aplicação de $\mathrm{N}$ e $\mathrm{K}$ via água de irrigação em melão. Horticultura Brasileira. v.13, n.2, p.192195. 1995.

PRABHAKAR, B. S.; SRINIVAS, K.; SHUKLA, V. Yield and quality of muskmelon (cv. Hara madhu) in relation to soacing and fertilization. Progressive Horticulture, v.17, n.1 1985, p.51-55.

RAIJ, B. van. Fertilidade do solo e adubação. São Paulo: Agronômica Ceres, 1991. 136p.

RANZANI, G. Carta de solos do município de Piracicaba. Piracicaba: ESALQ, Centro de Estudos de Solos, 1966. 85p.

RICHARDS, L.A. Porous plate apparatus for measuring moisture retention and transmission by soil. Soil Science, v.66, p.105-110, 1948.

SCATOLINI, M. E., Estimativa da Evapotranspiração da Cultura de Crisântemo em Estufas a Partir de Elementos Meteorológicos. Piracicaba 1996. 71p. Tese (Doutorado)-Escola Superior de Agricultura "Luiz de Queiroz", Universidade de São Paulo. 
SHMUELI, M.; GOLDBERG, S. D. Riego por asperción, por sulco y por gotejo del melón una zona árida. Jerusalem: Universidad Hebrea de Jerusalem, 1971. 5p.

SILVA, E.F.F., MIRANDA, J.H., COELHO, R.D. Determinação da salinidade do solo utilizando extratores de cápsulas porosas e soluções diluídas (compact disc.). In: CONGRESSO BRASILEIRO DE ENGENHARIA AGRÍCOLA. 28., Pelotas: 1999. Anais. Pelotas: SBEA, 1999.

SILVA,F.C. Uso de dispositivos lisimétricos para a medida da evapotranspiração de referência. Piracicaba, 1996. 73p. Dissertação (Mestrado) - Escola Superior de Agricultura "Luiz de Queiroz", Universidade de São Paulo.

SILVA, H. R; MAROUELLI, W. A; SILVA, R. A; OLIVEIRA, L. A; RODRIGUES, A. G; SOUZA, A. F.; MAENO, P. Cultivo do meloeiro para o norte de Minas Gerais. Brasilia: EMBRAPA, HORTALIÇAS, 2000. 22p. (Comunicação Técnica 20).

SILVA, W.L.C.; CARRIJO, O.A.; MAROUELLI, W.A. Fertirrigação na EMBRAPA Hortaliças. In: FOLEGATTI, M.V. (Coord.) Fertirrigação: citrus, flores, hortaliças. Guaíba: Agropecuária, 1999. cap.5, p.433-440.

SIVIERO, P.; GALLERANI, P. La cultivazione del melone. Verona: L'Informatore Agrário, 1993. 208p.

SOUSA, V. F. Freqüência de aplicação de N e K via irrigação por gotejamento no meloeiro (Cucumis melo L. cv. Eldorado 300) Botucatu, 1993. 131p. Dissertação (Mestrado)-Faculdade de Ciências Agronômicas, Universidade Estadual Paulista. "Júlio de Mesquita Filho".

SOUSA, V. F. Niveis de Irrigação e Doses de Potássio aplicados via fertirrigação por gotejamento no maracujazeiro amarelo (Passiflora edulis Sims. f. flavicarpa Deg) Piracicaba, 2000. 178p. Tese (Doutorado)-Escola Superior de Agricultura "Luiz de Queiroz", Universidade de São Paulo. 
SOUSA, V. F.; SOUSA, A. P. Efeito da freqüência de aplicação de $\mathrm{N}$ e K por gotejamento na cultura do meloeiro (Cucumis melo L.) Engenharia Agrícola, v.17, n.3, p.36-45, 1998.

SOUSA, V. F.; COELHO E.F.; BASTOS, E. A.; FOLEGATTI, M. V.; COELHO, E. F.; SOUSA, V. A. B. Freqüência de irrigação em meloeiro cultivado em solo arenoso. Pesquisa Agropecuária Brasileira, v.34, n.4, p.659-664, 1999.

SOUSA, V. F; RODRIGUES, B. H. N; SOBRINHO, A. C; COELHO, E. F; VIANA, F. M. P; SILVA, P. H. S. Cultivo do meloeiro sob fertirrigação por gotejamento no Meio Norte do Brasil. Teresina: Embrapa Meio-Norte, 1999. 68p.

SRINIVAS, K.; PRABHAKAR, B. S.; Response of muskmelon (Cucumis melo L.) to varying lends of spacing and fertilizer. Journal of Primary Industries, v.12, n.1, p.36-62, 1984.

SUAREZ, D. F. demanda de nitrógeno y eficiência de la fertiliación de melón reticulado (Cucumis melo L. var reticulatus Naud). Ciência e Investigación Agraria, v.18, n.3, p.101-110, 1991.

VAN GENUCHTEN, M.Th. A closed-form equation for predicting the hydraulic conductivity of unsaturated soils. Soil Science Society of America Journal, v.44, n.3, p.892-898, 1980.

VIEIRA, V. C. R.; CURY, D. M. L. Graus-dia na cultura do arroz. in: CONGRESSO BRASILEIRO DE AGROMETEOROLOGIA, 10., Piracicaba, 1997, Anais. Piracicaba: SBA, 1997. p. 47-49.

VILLA NOVA, N.A. Principais métodos de estimativa de aplicação de água de irrigação. Piracicaba: ESALQ, Departamento de Física e Meteorologia, 1987. 22p.

VIVANCOS, A. D. Fertirrigacion. Madri: Mundi-Prensa, 1993. 217p. 
YANG, S; LOGAN, J.; COFFEY, D. L. Mathematical formulae for calculating the base temperature for growing degree days. Agricultural and Forest Meteorology, v. 74, p.61-74, 1995.

WILLIAMS, C. N. Fertilizer responses of cuncubers on peat in brunei. Experimental Agriculture, v.14, p.299-302, 1978. 